\title{
Aggravation of Human Diseases and Climate Change Nexus
}

\author{
Mohd Danish Khan ${ }^{1,2}$, Hong Ha Thi Vu ${ }^{2}$, Quang Tuan Lai ${ }^{1,2}$ and Ji Whan Ahn ${ }^{2, *}$ \\ 1 Resources Recycling Department, University of Science and Technology, (UST), 217, Gajeong-ro, Yuseong-gu, \\ Daejeon-34113, Korea \\ 2 Center for Carbon Mineralization, Mineral Resources Research Division, Korea Institute of Geosciences and \\ Mineral Resources (KIGAM), 124 Gwahak-ro, Yuseong-gu, Daejeon-34132, Korea \\ * Correspondence: ahnjw@kigam.re.kr; Tel.: +82-42-868-3578
}

Received: 17 July 2019; Accepted: 1 August 2019; Published: 6 August 2019

\begin{abstract}
For decades, researchers have debated whether climate change has an adverse impact on diseases, especially infectious diseases. They have identified a strong relationship between climate variables and vector's growth, mortality rate, reproduction, and spatiotemporal distribution. Epidemiological data further indicates the emergence and re-emergence of infectious diseases post every single extreme weather event. Based on studies conducted mostly between 1990-2018, three aspects that resemble the impact of climate change impact on diseases are: (a) emergence and re-emergence of vector-borne diseases, (b) impact of extreme weather events, and (c) social upliftment with education and adaptation. This review mainly examines and discusses the impact of climate change based on scientific evidences in published literature. Humans are highly vulnerable to diseases and other post-catastrophic effects of extreme events, as evidenced in literature. It is high time that human beings understand the adverse impacts of climate change and take proper and sustainable control measures. There is also the important requirement for allocation of effective technologies, maintenance of healthy lifestyles, and public education.
\end{abstract}

Keywords: climate change; infectious diseases; pathogens; vectors; human adaptation

\section{Introduction}

Climate change is a significant statistical shift in regional or global climate variables over a considerable period of time (decades or even more). The most sensitive climatic variables include precipitation pattern, humidity, average and peak temperatures, and wind [1]. Although the global mean temperature and other climatic variables were relatively stable for millennia, recent decades have witnessed considerable changes [2]. The European Environment Agency reported a rise of $0.74{ }^{\circ} \mathrm{C}$ in global mean temperature in the 20th century, a continuous $1.8 \mathrm{~mm}$ per year expansion of sea level since 1961, and a 2.7\% reduction in Arctic sea ice per decade [3]. Climate experts have also confirmed the dramatic increase in the frequency and severity of extreme weather events over the last few decades. Moreover, a remarkable rise of $1.5^{\circ} \mathrm{C}$ to $5.8^{\circ} \mathrm{C}$ in global mean temperature was predicted by the Intergovernmental Panel on Climate Change (IPCC) in the 21st century, accompanied by more severe weather events dominated by floods and droughts $[4,5]$. Climatologists have also provided very clear evidence that even a short-term climatic variation can pose serious threat to human health in many different ways.

Climatic variations can significantly influence human health through the emergence of various infectious diseases [6-9]. Pathogens, vectors, and favorable transmission conditions are the three essential components involved in most infectious diseases [7]. Optimum climatic conditions are a prerequisite for reproduction, survival, mortality, and spatiotemporal distribution of vectors and 
disease-causing pathogens. Therefore, a sudden or long-term climate change can have a positive impact over infectious diseases $[7,10]$. Numerous studies have divulged the continual impact of rising rates of warming on the geographic expansion of pathogen-based diseases [11-19]. Studies also have found that increased global temperature boosted skin-related diseases [20]. More cases and hospital admissions have been reported regarding cutaneous injuries from marine and aquatic organisms that have expanded their habitats due to favorable warm water environments, such as cercarial dermatitis, jellyfish envenomation and melioidosis [21,22]. Furthermore, extreme weather events can also motivate the emergence and re-emergence of clustered diseases in many other non-traditional regions [6]. Conclusively, climatic conditions modulate the seasonal and geographic distribution of vector-borne diseases, and weather influences the severity and timing of disease outbreaks [10,23].

The inter-relationship amidst contagious pathogenic activities, vectors' susceptibility, and climatic variations have been a topic of great interest. As an example, any modulating factor that prolongs the 'stochastic trends of disease transmission' also permit pathogens to acclimate to the intermediate host and aggrandize disease evolution [24]. Being an inherent module of this rubric, climate change act as a background context and if changed, affects the susceptibility and transmission of infectious diseases. This research put forward a systematic literature review covering numerous scientific evidences, which highlight the effects of climate change and weather events on human-based diseases. Precisely, the present study provides a reconnaissance for the scrutinized and predicted impacts of climate change and weather events over disease-causing pathogens and vectors. The research also underlines the need for future studies by discussing the voids in research progress, productive policies and human adaptation.

\section{Methods}

As discussed earlier, the consequences of climate change on a variety of human diseases can be well examined based on two components: Emergence and re-emergence of pathogenic diseases, vectors, and favorable conditions for transmission and infectious disease outbreaks post weather events. Moreover, as the discussion is in context of human beings, human response and adaptation efficacy can be vital in mitigating the adverse impacts of climate change. The interconnections between climate change, extreme weather events, diseases, and human responses, forming the rationale for the present literature search, are illustrated in Figure 1.

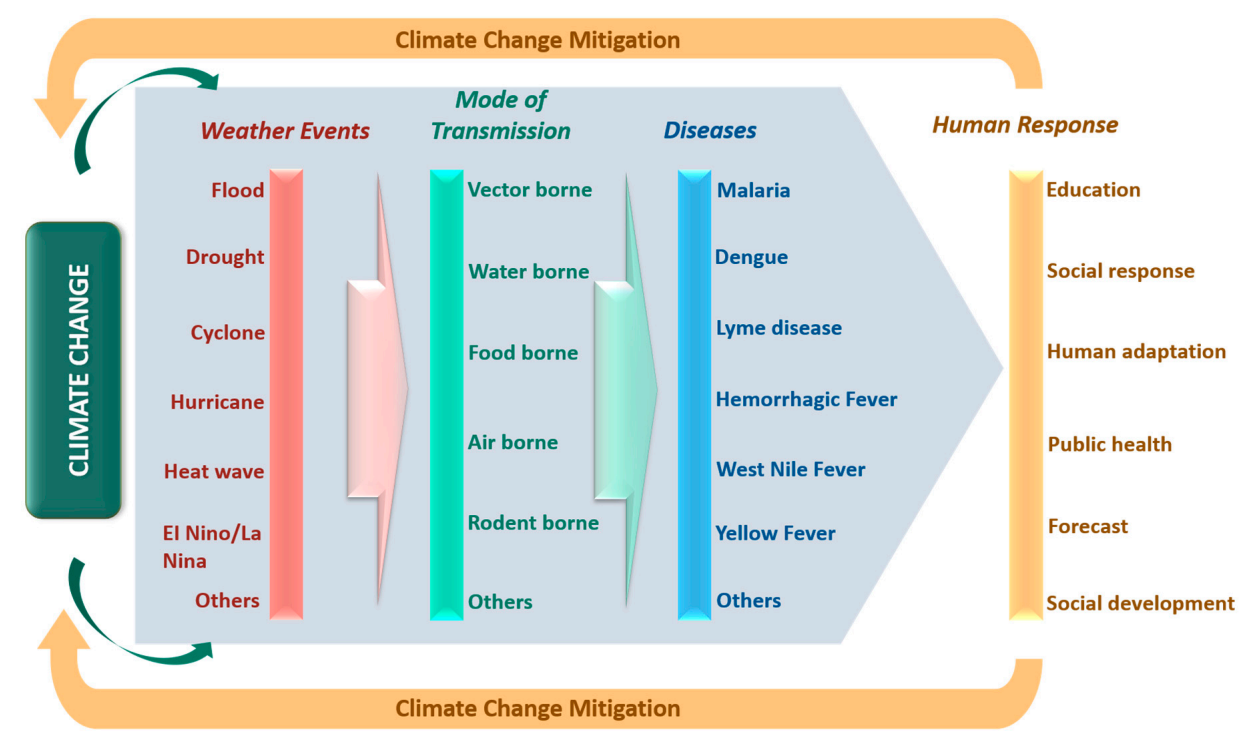

Figure 1. The relationships between climate change, extreme weather events and associated diseases with their mode of transmission. It also further represents possible urgent human responses for mitigation of climate change adapted from [1-6,21-24]. 
Literature searches in the present work were conducted through ScienceDirect, PubMed, PLOS, Google Scholar, Nature.com and MDPI. Furthermore, published reports provided by IPCC, UNICEF and WHO were also reviewed, where required. The primary focus was to collect peer-reviewed literature published between 1990 and 2018 to gather maximum scientific facts and evidences.

The Medical Subject Heading (MeSH) terms searched in PubMed, ScienceDirect and PLOS were: Viral infections, bacterial infections, pathogens, vectors, parasites, rodents, infectious diseases, diseases, skin diseases. "PECOT" terms included population, exposure, comparison, outcome and time. Climatology terms included temperature, humidity, wind, rain, precipitation, climate, climatic, extreme weather; extreme weather events were also searched. Other keywords such as Africa, Asia, Europe, South America, Australia, Canada, United States, policies, adaptation, population, exposure, human, response, education, public health, social response, outcome and time were also searched. The mentioned terms were coherent with those used in the previous review [25], but additional terms such as "policies," "adaptation," "social response," "ocean warm-up," "time," "exposure," and "population" were added. MeSH terms were preferred rather than individual keywords, as used in previous reviews $[25,26]$. As MeSH terms were used for the PubMed, ScienceDirect and PLOS searches, keywords contained significant phrases in the MeSH hierarchy. For instance, terms such as malaria, dengue, yellow fever, lyme, encephalitis and zoonoses are all included in "infectious diseases", a hierarchical MeSH phrase. The term "zoonoses" was not searched separately, rather the phrase "zoonotic diseases" was used because viral and bacterial infections and parasitic diseases all fall within their MeSH hierarchy.

For literature searches in Nature.com, Google Scholar, MDPI and government reports, the following keywords were used: infectious diseases, pathogens, vectors, viral infection, bacterial infection, extreme climatic events, climate change, temperature, precipitation, ocean warm-up, disease transmission, policies, adaptation, human, response, education, public health and social response. The mentioned searched terms were precisely chosen to explore across databases and to fulfill the selection criteria as much as possible.

Although numerous literatures were searched across databases, the only limitation found was the unavailability and security issues in accessing recent government reports with proper facts and figures for an individual country based on 'impact of climate change on human diseases'. Economic constrains were another factor that hindered any possible access to relevant government official databases.

The search criteria were based on the following requirements: (a) articles and reports with a considerable correlation between the climatic variable and human diseases. The source of those diseases can be a pathogen or a vector/host whose survival or activities can be significantly influenced by climatic factors. (b) Climate change and required human response. The human response can involve relevant policies, education, adaptation measures and social response. No region-wise restriction and data from across the globe was considered. All searches were conducted from July 2018 onwards till 30 November 2018.

All the search terms used, and the number of results retrieved for each search in various databases were recorded. To determine each article's relevance, their titles and abstracts were carefully evaluated. All the articles that fell within the criteria were extracted for a detailed text review. Those articles that met the selection criteria post detailed text reviews were included in the present work. All duplicate articles in different databases were counted as single articles and were selected from the first database they were found in. Figure 2 depicts the numbers of search outcomes, reviewed articles and articles included in this review across databases.

Initially, more than 750 peer-reviewed publications were retrieved from databases. After title and abstract evaluation, 300 articles were selected based on inclusion criteria. Finally, post full text review analysis, a collection of 163 articles and reports were schematically included in the present work. Those articles and reports comprehensively focus on numerous consequences of climate change over human diseases and highlight the urgent requirement for a human response. 

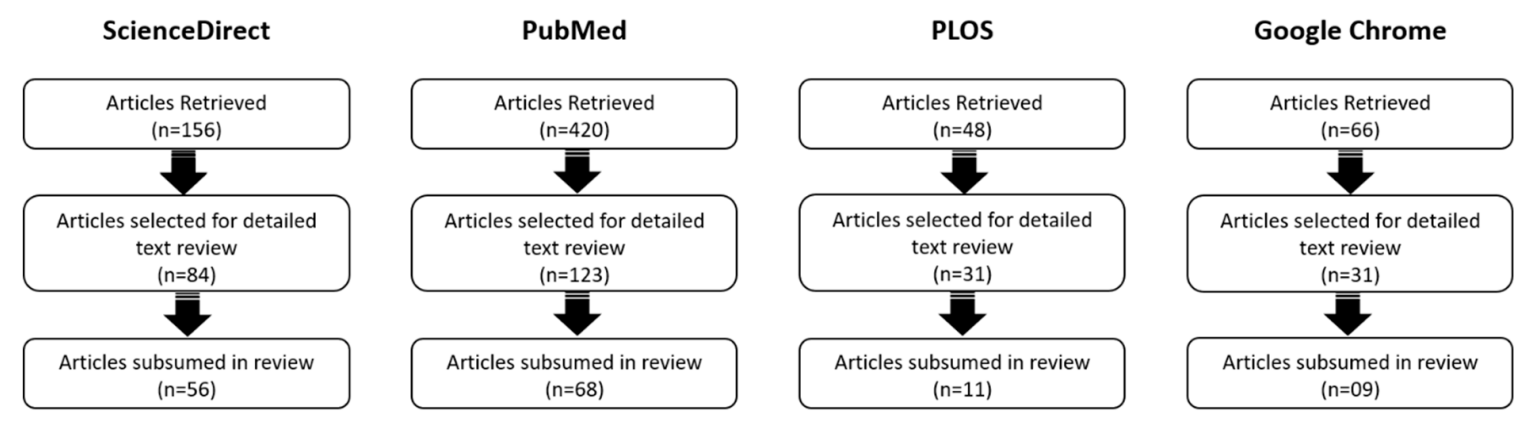

Nature.com/Science

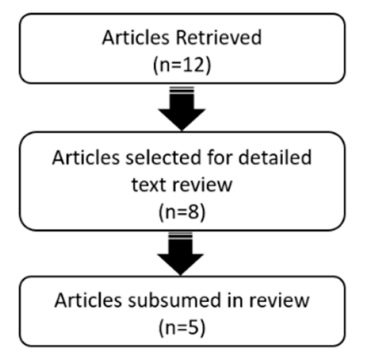

MDPI

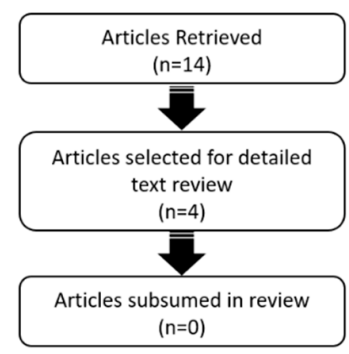

Reports

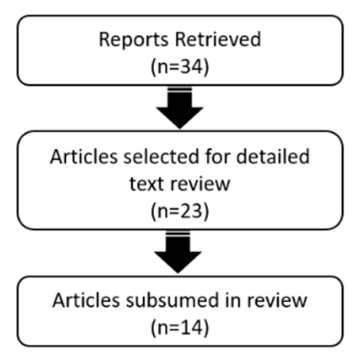

Figure 2. Illustration of the article-screening process across databases: Articles retrieved, articles selected for detailed text review, and articles subsumed in review (where $\mathrm{n}$ denotes the number of articles/reports).

\section{Extreme Weather Events}

Extreme climate/weather events represent the outcome of climatic variables that breach the threshold limits [27]. On a broader basis, these events can be categorized as global scale extreme events like El Nino, La Nina and Quasi-Biennial Oscillation (QBO), and regional scale events such as floods, droughts, and shift in precipitation and drought. Regional events are very rare ( $<5 \%$ of time) but their intensity and frequency are rising significantly, representing the adverse impact of climate change [27-29]. Extreme weather events may not only result in the huge spread of diseases through the increased growth of vectors, pathogens, viruses, and transmission routes, but can also cause a breakdown of public health infrastructure, loss of sanitation and hygiene, shortage of drinking water supply, and increased concentration of people.

Many studies have been conducted on the consequences of global and regional weather events on human diseases, as depicted in Table 1. Majority of these studies are empirical rather than comprehensive. They lack the real mechanism between climate change and various diseases and often contradict each other. As an example, a study by Nicholls revealed that in Peru, Ecuador and Bolivia, the outburst of malaria was due to heavy rainfall caused by an El Nino event around 1983 [30]. However, it was also found that there is no link between hospital admission and climate change based on malaria in East Africa under the El Nino event [31,32]. Another study found a sudden downfall in malaria cases in regions of the Usambara Mountains, Tanzania after the 1998 El Nino event. Similar contradictions were found for the case of Rift Valley Fever (RVF) epidemics. In the dry grassland regions of East Africa, heavy rainfall was found responsible for the epidemics of RVF [33,34]. However, in Kenya, no association was identified between El Nino and RVF and also no correlation was noted between heavy rainfall variability and El Nino [33].

Many researchers have claimed climate change to contribute to cardiopulmonary disorders such as acute coronary syndromes, infarction and other similar mortalities [35-39]. Although climate change may seem to provide some health benefits (in early stages) in such disorders [1], they pose much more health hazards. A warmer climate produces much intense heat waves on a frequent basis, the negative effects on which on human health are well-known [40]. Incidences of cardiovascular and respiratory diseases in children as well as in adults have increased tremendously from the last century [41]. A close 
relationship had been found between hospital admission, environmental temperature, and humidity for angina pectoris [42]. Another research in the US revealed that humidity with higher temperatures resulted in an increment of asthma patients' visits to hospitals [43,44]. Numerous model projects based on the climate in Europe and North America provided evidence for $50 \%$ increment in intensity and frequency of hottest days in the $21^{\text {st }}$ century $[45,46]$. In the US, more than 400 deaths are reported annually due to excessive heat-related sickness [47]. Recent studies also confirmed the association between higher temperature and myocardial infarction along with congestive heart failure due to excessive heat $[48,49]$. A detailed understanding of change in climate patterns and combined climate effects on human health is highly desirable. This not only provides support in predicting health effects from weather-related events but also plays a potential role in effectively controlling many diseases.

Variations in the magnitude of weather events might also be responsible for a variety of health effects. For example, a study conducted by Chen et al. found that cases of Hemorrhagic Fever with Renal Syndrome (HFRS) increased during the floods in 1954, 1975 and 1991, implicating HFRS with floods directly [50]. However, in the flood incident of 1998, HFRS cases reduced significantly, contradicting previous findings. Finally, further research revealed that the rodent population was ultimately responsible for HFRS, which reduced greatly in regions affected by floods in 1998. A similar kind of study was performed by Pan et al. in which the main reason for HFRS was related to variable water levels in flooded areas [51]. Some studies were also performed on weather events such as hurricanes and cyclones $[6,52,53]$. The aftereffects of those events on human health were seen as a widespread increase of malaria, dengue, leptospirosis, and cholera. Lastly, heat and drought are mainly responsible for wildfire in many parts of the world. Smoke from wildfires can cover a wide area exposing people to hazardous gases and particulate matters $[54,55]$. The above examples illustrate the lack of enough data as well as contradictions among studies, highlighting the limited ability to predict diseases and any change related to their course or intensity during different weather events. Hence, there is the utmost requirement to accurately predict all possible changes in climate variables that are expected to be associated with extreme weather events. 
Table 1. Key studies highlighting the impacts of extreme weather events on human diseases.

\begin{tabular}{|c|c|c|}
\hline Extreme Weather Events & Main Outcomes & References \\
\hline El Nino & $\begin{array}{l}\text { Found responsible for the outbreak of Malaria in Peru, Bolivia and Ecuador due to extreme } \\
\text { rainfall in } 1983 \text {. } \\
\text { The effect of El Nino varied by region. San Francisco and Los Angeles evidenced } 30-50 \% \text { rise in } \\
\text { hospitalization with a decrease of } 5{ }^{\circ} \mathrm{C} \text { in minimum average temperature due to influenza } \\
\text { epidemics. However, } 25-40 \% \text { hospitalizations were observed in Sacramento with just } 5^{\circ} \mathrm{C} \text { in } \\
\text { maximum average temperature. }\end{array}$ & $\begin{array}{l}{[30]} \\
{[56]}\end{array}$ \\
\hline La Nina & $\begin{array}{l}\text { La Nina events cause outbreaks of Japanese encephalitis and West Nile Virus. } \\
\text { Occurrence of drought due to the La Nina event was linked to the chikungunya fever epidemic }\end{array}$ & $\begin{array}{l}{[30]} \\
{[57]}\end{array}$ \\
\hline Quasi-Biennial Oscillation (OBQ) & OBQ was confirmed as the main cause for the emergence of Ross River virus in Queensland. & [58] \\
\hline Drought & $\begin{array}{l}\text { Among various categories of drought, agricultural drought is the most severe, and many farmers } \\
\text { suffer from mental disorders due to significant losses in crop production. Many end up } \\
\text { committing suicide. }\end{array}$ & [59] \\
\hline Heat Waves & $\begin{array}{l}\text { A positive relationship was observed between hospital admission, excessive heat and humidity } \\
\text { due to the emergence of angina pectoris. } \\
\text { On an annual basis, more than } 400 \text { children in the United States die of heatwave-related } \\
\text { sicknesses such as diarrhea, typhoid and jaundice. } \\
\text { Recent studies provide reliable evidence on the direct relationship between heatwaves and } \\
\text { myocardial infarction with congestive heart failure. }\end{array}$ & $\begin{array}{l}{[47]} \\
{[48,49]}\end{array}$ \\
\hline Flood & $\begin{array}{l}\text { A direct association was observed between gastroenteritis and intensity of flood at Lewes in } \\
\text { Southern England. }\end{array}$ & {$[60]$} \\
\hline Hurricane & Honduras and Venezuela evidenced malaria and dengue outbreak post a hurricane event. & [6] \\
\hline Cyclone & Cyclone events remarkably increase leptospirosis and cholera incidences. & {$[52,53]$} \\
\hline
\end{tabular}




\section{Relationship Between Climate Change and Transmissible Diseases}

Climate change can be directly or indirectly detrimental to human health. To date, a majority of the investigations were confined to direct effects of climate change; for instance, heatwaves, floods, drought, hurricane, cyclone and other extreme weather events $[27,61]$. It was recently identified that the indirect effects of climate change in terms of infectious diseases are also severe and unlike direct effect could last for a longer period of time over a much wider region [37,38]. Climate change can alter environmental temperature, wind, and precipitation patterns, which can indirectly affect pathogen distribution, vector reproduction rates, and transmission media. These effects then further determine regional shifts in seasonal patterns of individual diseases along with its respective frequency and severity. In this section, the impacts of climate change over infectious diseases have been systematically surveyed primarily over impacts on pathogens, vectors or hosts, and mode of transmission. Empirical findings related to pathogens, vectors and associated diseases are summarized in Table 2.

\subsection{Impact on Pathogens}

Pathogens refer to a broad variety of disease-causing agents such as bacteria, viruses, fungi and other microorganisms, and parasites. Till date, there are more than 1400 known species of human pathogens. These pathogens are mostly transmitted to humans either zoonotically $(60 \%)$ or other environmental mediums ( 10\%). Zoonotically transmitted pathogens require an animal body as their habitat for survival. The remaining pathogens can be directly transmitted human-to-human [62]. The emergence and re-emergence of zoonotic infections are much higher (around $73 \%$ ), representing the associated risk of human-animal interface [63]. These pathogens can be affected with the changes in climate directly through alterations in reproduction mechanism and survival behavior. Indirectly, it can affect by influencing the environment, particularly their habitat. Therefore, climate change can potentially enhance quantity and can also induce a major shift in the distribution of pathogens [26].

Temperature has a most significant impact on transmission and life cycle of pathogens. In a review study by Mellor and Leake, it was concluded that environmental temperature greatly controls the transmission of Japanese Encephalitis Virus (JEV) [64]. For example, at $28^{\circ} \mathrm{C}$, transmission of JEV by Culex. tritaeniorhynchus was $60 \%$ and $100 \%$ after 9 and 14 days, respectively. However, at $20{ }^{\circ} \mathrm{C}$, no transmission was recorded, even after 20 days of monitoring. Another study also highlighted that threshold temperatures i.e., a maximum of $22-23^{\circ} \mathrm{C}$ for developing mosquitoes and a minimum of $25-26^{\circ} \mathrm{C}$ for transmission of JEV determines the ecology of JEV [65]. Excessive temperature rise can also favor pathogens in their reproduction mechanism in terms of the extrinsic incubation period (EIP) [11]. For instance, in the case of Plasmodium falciparum, it is found that at $20^{\circ} \mathrm{C}$ the EIP is around 26 days, which reduces to only 13 days at a temperature of $25^{\circ} \mathrm{C}$ [66]. During summer periods, an increase of about $40 \%$ infections associated with Enterobacter cloacae was also found [67]. A similar dependence of increasing temperature on Klebsiella pneumoniae bloodstream infection was also investigated by Anderson et al. [68]. A positive relationship between warm wet season and growth of Acinetobacter spp. related infectious diseases were also revealed by Allen at al. [22]. There are also some positive implications of extreme heat and mortality rates for some pathogens [23]. For instance, the growth of parasites such as Plasmodium spp. associated with malaria minimizes when temperatures surmount $38-39{ }^{\circ} \mathrm{C}$ [69]. Global warming might also induce genetic modifications in pathogens like chikungunya viruses, which might make them more resilient and reproduce at faster rate [70]. Extreme hot weather is reported to have adverse impacts on aquatic environments, often leading to an exponential rise in microorganisms. It was found that the growth rate of Vibrio spp. was much higher on hotter days when compared to normal days [71]. A positive correlation has been identified between Salmonella spp. growth and water temperatures, whereas in Escherichia coli, it was negative [72,73]. El-Fadel et al. developed a Poisson generalized linear model to identify and predict the relationship between waterand food-borne morbidity rates and associated high temperatures [74]. It has been observed that morbidity rates decrease to a threshold temperature of $19.2^{\circ} \mathrm{C}$ and then increases with temperature. 
It has also been predicted that by the year 2050, water and food-borne morbidity rates will rise to $28 \%$, which can further increase to $42 \%$ by the end of 2100 .

Climate change can also significantly influence the precipitation pattern and humidity level, which in turn could provide a beneficial environment for some water-borne and air-borne disease pathogens. Considerable rain after dry periods can cause a potential outbreak of diseases due to the development of a variety of pathogens [75]. Heavy rainfall resulting in overflows carries fecal coliforms to distant areas along with widespread accumulations under soil and sediments [76]. Temperature and humidity also play a key role in the transmission of influenza A virus (H1N1) [77]. It has been identified that transmission of influenza virus occurred more in cold and relatively less humid conditions [78]. Thu et al. analyzed the impact of relative humidity and rainy season over dengue virus propagation in Yangon and Singapore [79]. The results revealed that dengue virus concentration increased remarkably in relative humidity and rainy season in both the regions.

Some literatures also suggested the involvement of wind in air-borne diseases. Chen et al. performed an experiment using quantitative polymerase chain reaction (qPCR) to find the impact of Asian dust storms (ADS) on influenza virus concentration. The results highlighted that during ADS periods, the concentration of H1N1 influenza virus was substantially higher compared to other days [80].

\subsection{Impacts on Vectors/Hosts}

Ever-increasing human population, unplanned urbanization, restricted habitats, improper land use, and climate are the major factors involved in the emergence and re-emergence of diseases [81]. However, it has also been identified that intrinsic sensitivity of arthropods towards climate change forces the emergence and re-emergence of a variety of infectious diseases [25]. The host can be any living macro-organism such as animals or plants. Vectors act as an intermediate host, which carry and transfer pathogen to host. This subsection explores the possible impacts that climate change and weather can impose on vectors. Past studies have provided enormous evidences of climate change impact over vectors and vector-borne diseases. These vectors are ectothermic in nature and therefore, their vectorial capacity greatly is affected by any change in temperature [82-84].

\subsubsection{Effect of Spatiotemporal Distribution of Vectors}

Temperature rise can lead to a major shift in the habitats of vectors. Vectors living in lower latitude regions can shift their habitat to mid or high latitudes, resulting in geographical amplification of vectors and related diseases. Vector-borne diseases such as lyme, malaria, yellow fever, dengue, and plague are some of the examples with wide geographical expansion in many parts of the world [11]. For instance, snail (Oncomelania hupensis) as a vector plays a vital role in the transmission of Schistosomiasis. A study conducted in China found that owing to a continuous rise in winter temperature, O. hupensis increased its range with widespread distribution, thereby spreading schistosomiasis over northern China [12]. Another detailed study in Nepal revealed the vulnerability of mountain regions to global climate change. It was found that the rate of warming in the Himalayas $\left(0.06{ }^{\circ} \mathrm{C} /\right.$ year $)$ was much greater than the global average warming rate [85]. The consequences of the high rate of warming in these regions were found in terms of spatiotemporal distribution of vector-borne diseases. Firstly, malaria which was confined to the forest and nearby areas of Terai, around 38 districts in Nepal lowlands, has now expanded to mountains covering around 65 districts of Nepal [86-88]. In total, 44 species of Anopheles mosquitoes were estimated to be affected and among them 7 (i.e., Anopheles fluviatilis, An. dravidicus, An. willmori, An. minimus, An. pseudowillmori, An. maculatus, and An. annularis) were responsible for the transmission of malaria. Similar trends were also observed for dengue [89-91]. One more vector-borne disease, Japanese encephalitis transmitted by mosquito species Culex tritaeniorhynchushas, rose northwards in India and became an endemic in Nepal [13]. Initially reported in 24 districts of the lowland Terai, Japanese encephalitis was transmitted to other mountain regions including 
Kathmandu [14,15]. Lastly, visceral leishmaniasis and lymphatic filariasis were other vector-borne diseases whose spatiotemporal distribution were reported due to global warming [16-19].

Ticks, another disease-transmitting vector, is found to be greatly affected by global warming in terms of survival and reproduction rates largely due to increase in winter temperatures [92,93]. A recent study in Sweden provided clear evidences for the expansion and distribution of tick Ixodes ricinus [94]. From 1990 to 2008, tick's coverage area expanded almost twice i.e., from $12.5 \%$ to $26.8 \%$ with major expansion occurring in the northern region. A different study conducted in Russia reported a significant rise in the population of Ixodes ricinus over a period of 1977 to 2011 in eastern Tula region [95]. These studies highlighted that the expansions were mainly due to milder winters and extended spring and autumn seasons along with some adverse human activities such as decimation of forest and over exploitation of coal and petroleum reserves, which ultimately promote global warming.

\subsubsection{Effect on Mortality Rate}

Temperature mostly has a direct influence on the mortality rate of vectors; however, the limited understanding and complexity of the relationship between vectors, disease transmission, and surrounding environment urge more detailed research [96,97]. Among the variety of vectors, mosquitoes have been found to be much more susceptible to threshold temperature limits [98]. For instance, a study conducted in Changsha, China, identified that a temperature of $22-23^{\circ} \mathrm{C}$ is optimal for the development of mosquito larvae, while $25-26{ }^{\circ} \mathrm{C}$ is suitable for JEV, as it exceeds the breeding temperature, and the tendency of being infected also rises significantly [65]. Recent studies also investigated the impact of different water temperature on the mortality rate of larval and adult dipteran vectors $[99,100]$. These larval and pupal stages of dipteran vectors are more sensitive to diurnal variations in regional temperature than global variation in temperatures [101]. However, there are two major factors which determine the probability of vector population survival in the geographical regions where climatic conditions surpasses the threshold limits: (a) the capacity and tendency of the vector to espy refuge from extreme conditions; (b) capacity of surrounding environment or vector habitat to provide opportunities for refuges [102].

Among most of the positive effects of extreme climatic conditions on vector's mortality, there are some vectors whose growth are restricted, thereby a reduction can be observed in the distribution of disease vectors. For instance, viruses responsible for yellow fever and dengue are carried and transmitted by the Aedes aegypti mosquito [7]. Previous studies found that the growth of A. aegypti larvae ceases when the temperature of habitat water exceeds $34^{\circ} \mathrm{C}$. Moreover, as the air temperature reaches $40^{\circ} \mathrm{C}$, the adult $A$. aegypti concentration also starts to collapse [103]. With a continuous rise in global temperature, disease vectors such as $A$. aegypti may vanish in regions where temperature surpasses their thresholds. Another example includes the case of the Anopheles mosquito, vector for Plasmodium falciparum, a causative agent of malaria. These mosquito vectors can only survive above $16^{\circ} \mathrm{C}$, thereby on dropping the temperature below it aids control measures over malaria epidemics [104].

Precipitation can play a dual role in the distribution of disease vectors, although most of the vector growth accelerates during rainfalls with increasing temperature [105]. A study conducted in Mexico found that rainfall significantly increases rodent population and was responsible for the cocoliztli outbreak in Mexico [106]. However, excessive precipitation can have adverse impacts on larvae growth, as heavy rain may mop off their breeding sites [23]. For example, Culex, a mosquito genus which carries the West Nile virus, generally breeds in grubby water pools and drains. Heavy rainfall can wash off the drains, thereby limiting the growth of Culex and hence reducing transmission of the West Nile virus [107]. In case of drought, studies have found a contrasting effect on vector's growth, especially mosquitoes. Adult Anopheles, which mostly breeds in clean and stagnant water, were significantly affected by drought due to a severe reduction in breeding sites [108]. Contrary to this, another study on the impact of drought highlighted a reduction in the flow of water in brooks, which ultimately introduces small pools and patches of putrid water that act as perfect breeding sites [109]. 


\subsection{Mode of Transmission}

Disease transmission can be categorized as direct and indirect transmission. Direct transmission to humans basically includes transmission through physical contact, droplet transfer, and by using infected formites. Indirect transmission to humans mostly occurs with the involvement of vectors or other organisms. Past studies have shown a positive involvement of climate variables and extreme weather conditions in the transmission of diseases, although the transmission mechanism is not well understood yet. This subsection discusses the impacts and consequences of climate change on the transmission of diseases in humans.

Wind can play an important role in the transmission of air-borne pathogens and viruses. Wind storms and other similar calamities hold great potential for transmission of viruses and pathogens from endemic regions to other distant regions. As an example, it has been proved that Asian Dust Storms (ADS) were involved in a widespread transmission of the H1N1 influenza virus [80]. Some studies even concluded that ADS can carry those influenza viruses from Asia to the Americas during winters through prevailing winds [110]. Wind can also have a dual impact on disease-causing vectors. One example related to all species of mosquitoes is that strong winds can significantly minimize biting opportunities but also provide aid in spatial distribution, thereby increasing disease transmission probability [111].

Climate change can also alter the probability of disease transmission by increasing human-vector and human-pathogens contact. This can be well understood with Aedes species bloodmeal digestion patterns, which change with temperature. The quicker this species digests their bloodmeal, the more opportunity they will have to search for and hence increase chances of transmission [112]. For example, at $8{ }^{\circ} \mathrm{C}$, Aedes larvae develop in 38 days, whereas at $12{ }^{\circ} \mathrm{C}$, they last only for $18-20$ days; bloodmeal digestion generally takes 30 days at $4{ }^{\circ} \mathrm{C}$ and just 5 days at $20^{\circ} \mathrm{C}$; in the case of embryonic developments, it takes 42 days at $4{ }^{\circ} \mathrm{C}$ whereas only 22 days at $12{ }^{\circ} \mathrm{C}$ and just 8 days at $20{ }^{\circ} \mathrm{C}$ [112,113]. Sandfly, another vector which can transmit leishmaniasis, an infection caused by Leishmania spp. Temperature greatly manipulates the biting activity and maturation of Leishmania infantum in infected sandfly [114]. It was found that the biting behavior of sandfly is more common in summer seasons, although too hot and dry conditions can be detrimental for sand flies. Campylobacteriosis, a bacterial gastrointestinal disease is stimulated by thermophilic Campylobacter spp. bacteria. Researchers found that broiler and poultry meat were major infection transmission sources [115]. Further study also revealed that the colonization of campylobacter, along with those meats, have an exponential relationship with rising temperature [116].

A key element for pathogen transmission and their spatiotemporal occurrence is the Extrinsic Incubation Period (EIP). EIP specifically refers to the time interval between ingestion of pathogen by the fly from an infected person and the release of the same pathogen while feeding another person, thereby causing multiplication and propagation of complex sexual cycles [117]. Temperature greatly influences the tendency and occurrence of EIP [118] i.e., EIP occurs at a faster rate at rising temperatures. Contrary to this, at lower temperatures, EIP duration can be longer than fly life expectancy and therefore, even with abundant vector populations, the pathogen transmission cycles can cease.

Moreover, during too hot conditions, the mortality rate of fly can overcome the shortening effect of EIP, resulting in the upper threshold limit of temperature for transmission [119]. 
Table 2. Collection of key studies representing the impacts of climate change on pathogens, vectors and transmission of infectious diseases.

\begin{tabular}{|c|c|c|c|}
\hline Climate Impacted Variables & Emerged Diseases & Main Outcomes & References \\
\hline \multicolumn{4}{|c|}{ Pathogens } \\
\hline $\begin{array}{l}\text { Japanese Encephalitis Virus } \\
\text { (JEV) }\end{array}$ & $\begin{array}{l}\text { Japanese encephalitis } \\
\text { viral disease }\end{array}$ & $\begin{array}{l}\text { A temperature range of } 25-26^{\circ} \mathrm{C} \text { is best for transmission of JEV through } \\
\text { mosquitoes. }\end{array}$ & {$[64,66]$} \\
\hline Chikungunya Virus (ChikV) & Chikungunya viral fever & $\begin{array}{l}\text { Mild winters, summers times with temperature around } 20^{\circ} \mathrm{C} \text { and average } \\
\text { rainfall }(>50 \mathrm{~mm}) \text { is optimum for ChickV transmission. }\end{array}$ & [120] \\
\hline Campylobacter spp. & Campylobacteriosis & $\begin{array}{l}\text { Lower surface water temperatures are more favorable for their growth. At } \\
\text { higher water temperatures and more intense UV radiations, other bacteria can } \\
\text { out-compete them, which can lead to extinction of Campylobacter spp. }\end{array}$ & [121] \\
\hline Influenza Virus H5N1 & Bird flu/Avian Influenza & $\begin{array}{l}\text { H1N1 influenza virus concentration was found to be significantly higher } \\
\text { during Asian dust storms compared to other days. }\end{array}$ & [80] \\
\hline Influenza A virus H1N1 & Influenza (flu) & $\begin{array}{l}\text { Temperature and humidity enhance the transmission of influenza A virus } \\
\text { (H1N1). }\end{array}$ & [77] \\
\hline Dengue virus & Dengue & $\begin{array}{l}\text { The impact of relative humidity and rainy season over dengue virus } \\
\text { propagation were found to be responsible for the outbreak of dengue in } \\
\text { Yangon and Singapore. }\end{array}$ & [79] \\
\hline Leishmania spp. & Leishmaniasis & $\begin{array}{l}\text { Temperature greatly influences diapause and maturation of L. infantum in } \\
\text { infected sandfly. }\end{array}$ & [114] \\
\hline \multicolumn{4}{|c|}{ Vectors } \\
\hline $\begin{array}{l}\text { Plasmodium falciparum } \\
\text { (Mosquito) }\end{array}$ & Malaria & $\begin{array}{l}\text { P. falciparum grows at a faster rate in warmer temperatures i.e., it takes } 26 \\
\text { days for incubation at } 20^{\circ} \mathrm{C} \text { but only } 13 \text { days at } 25^{\circ} \mathrm{C} \text {. }\end{array}$ & [7] \\
\hline $\begin{array}{l}\text { Anopheles fluviatilis; } \\
\text { An. dravidicus; } \\
\text { An. willmori; } \\
\text { An. minimus; } \\
\text { An. pseudowillmori; An. } \\
\text { maculatus; and An. annularis }\end{array}$ & Malaria & $\begin{array}{l}\text { As a consequence of the rising rate of warming, significant spatiotemporal } \\
\text { distribution of vectors was observed in Nepal. Malaria, which was earlier } \\
\text { confined to forests near Tarai lowlands (in } 38 \text { districts), has expanded to } \\
\text { further } 68 \text { districts. }\end{array}$ & [86-88] \\
\hline Culex tritaeniorhynchushas & Japanese encephalitis & $\begin{array}{l}\text { Rising rate in warming forces Culex to find refuge and hence has expanded } \\
\text { from the northern part of India and became endemic in Nepal. }\end{array}$ & [13] \\
\hline
\end{tabular}


Table 2. Cont

\begin{tabular}{|c|c|c|c|}
\hline Climate Impacted Variables & Emerged Diseases & Main Outcomes & References \\
\hline \multirow{4}{*}{ Aedes aegypti } & \multirow{4}{*}{ Dengue } & $\begin{array}{l}\text { The continuous rise in temperature and changes in precipitation pattern } \\
\text { accelerates the growth of } A \text {. aegypti. }\end{array}$ & [122] \\
\hline & & $\begin{array}{l}\text { Precipitation can modulate the size, behavior and population of A. aegypti. } \\
\text { With rainfall }(>50 \mathrm{~mm}) \text {, significant cases of dengue were seen, whereas a } \\
\text { temporary decrease in cases was seen during extreme rainfall. }\end{array}$ & [123] \\
\hline & & $\begin{array}{l}\text { A significant spatiotemporal distribution of mosquitoes was observed over a } \\
\text { wide area due to rise in warming rate. }\end{array}$ & [89-91] \\
\hline & & $\begin{array}{l}\text { The growth of } A \text {. aegypti ceases when water temperature surpasses } 34^{\circ} \mathrm{C} \text { and } \\
\text { for the adult one if the temperature exceeds } 40^{\circ} \mathrm{C} \text {. }\end{array}$ & [103] \\
\hline Aedes spp. & $\begin{array}{l}\text { Malaria, Dengue, } \\
\text { Chikungunya }\end{array}$ & $\begin{array}{l}\text { Effect of temperature on Aedes species activities: } \\
\text { Larvae development: } \\
38 \text { days at } 8^{\circ} \mathrm{C} \text { and } 18 \text { days at } 12^{\circ} \mathrm{C} \text {. } \\
\text { Bloodmeal digestion: } \\
30 \text { days at } 4^{\circ} \mathrm{C} \text { and } 5 \text { days at } 20^{\circ} \mathrm{C} \text {. } \\
\text { Embryonic developments: } \\
42 \text { days at } 4^{\circ} \mathrm{C}, 22 \text { days at } 12^{\circ} \mathrm{C} \text { and } 8 \text { days at } 20^{\circ} \mathrm{C} \text {. }\end{array}$ & {$[112,113]$} \\
\hline $\begin{array}{l}\text { Aedes spp.; Haemagogus spp.; } \\
\text { Sabethes spp. } \\
\text { (Mosquito) }\end{array}$ & Yellow Fever & $\begin{array}{l}\text { Warmer climate encourages the growth of mosquito species, resulting in } \\
\text { outbreaks of yellow fever in Africa and South America. }\end{array}$ & [124] \\
\hline $\begin{array}{l}\text { Culex spp. } \\
\text { (Mosquito) }\end{array}$ & West Nile Fever & $\begin{array}{l}\text { The aggressiveness of Culex spp. was found to be strongly correlated with } \\
\text { humidity, rainfall and temperature changes. }\end{array}$ & [125] \\
\hline \multirow{2}{*}{$\begin{array}{l}\text { Ixodes Ricinus } \\
\text { (Tick) }\end{array}$} & \multirow[t]{2}{*}{ Tick-borne encephalitis } & $\begin{array}{l}\text { Faster development and increased activity with rise in humidity and } \\
\text { temperature. }\end{array}$ & [20] \\
\hline & & $\begin{array}{l}\text { Due to mild winters and extended spring and autumn, I. ricinus coverage area } \\
\text { increases from } 12.5 \% \text { to around } 26.8 \% \text { in Sweden during } 1990-2008 \text {. }\end{array}$ & [94] \\
\hline $\begin{array}{l}\text { Oncomelania hupensis } \\
\text { (Snail) }\end{array}$ & Schistosomiasis & $\begin{array}{l}\text { With continuous rise in winter temperature, O. hupensis widens its distribution } \\
\text { range, thereby spreading schistosomiasis in northern China. }\end{array}$ & [12] \\
\hline
\end{tabular}


Table 2. Cont.

\begin{tabular}{|c|c|c|c|}
\hline Climate Impacted Variables & Emerged Diseases & Main Outcomes & References \\
\hline \multicolumn{4}{|c|}{ Transmission } \\
\hline \multirow{2}{*}{ Influenza Virus H5N1 } & \multirow{2}{*}{ Bird flu/Avian Influenza } & The H5N1 outbreak is associated with wild fowl migration. & [126] \\
\hline & & $\begin{array}{l}\text { H5N1 viruses were found to be carried away to distant areas during Asian } \\
\text { dust storms. }\end{array}$ & [80] \\
\hline Hantavirus & $\begin{array}{l}\text { Hantavirus pulmonary } \\
\text { Syndrome }\end{array}$ & $\begin{array}{l}\text { During extreme conditions like floods, deer mice may approach human } \\
\text { dwellings in search of food and can transmit disease. }\end{array}$ & [127] \\
\hline Leishmania infantum & Leishmaniasis & $\begin{array}{l}\text { The biting activity of sand fly is found to be more common in summer months, } \\
\text { although too hot and dry conditions are not suitable for survival of sand flies. }\end{array}$ & [114] \\
\hline Campylobacter spp. & Campylobacteriosis & $\begin{array}{l}\text { Colonization of campylobacter along with those meats have an exponential } \\
\text { relationship with rising temperature. }\end{array}$ & {$[115,116]$} \\
\hline
\end{tabular}




\section{Need for Urgent Human Response}

Economic and social factors hold a great potential in understanding the changing patterns of climate and associated diseases $[10,77,128]$. It has been found that certain regions and communities are more vulnerable because of their inability to respond appropriately to weather events posed by climate change $[129,130]$. The threat of vulnerability can have two aspects: First, measures taken to abate weather and climate-associated risks through awareness programs, figuring out different diseases and biosecurity. Second, availability or access to safe and clean drinking water, hygienic food, and proper sanitation [131,132]. Uncontrolled and unplanned urbanization in India has left many regions highly vulnerable to diseases in wake of climate change. The country has seen a dramatic increase in malaria and dengue cases in the past decades. [133,134]. Likewise, communities with limited access to clean water are more vulnerable to diarrhea, as the ailment occurs more frequently in water-scarce regions [135]. However, an exception can also be seen in well-developed societies who have access to advanced technologies and hold alternative resources to eradicate the challenges imposed by water scarcity. Figure 3 illustrates the outline of social impacts of climate change on livelihood, human society and infectious diseases.

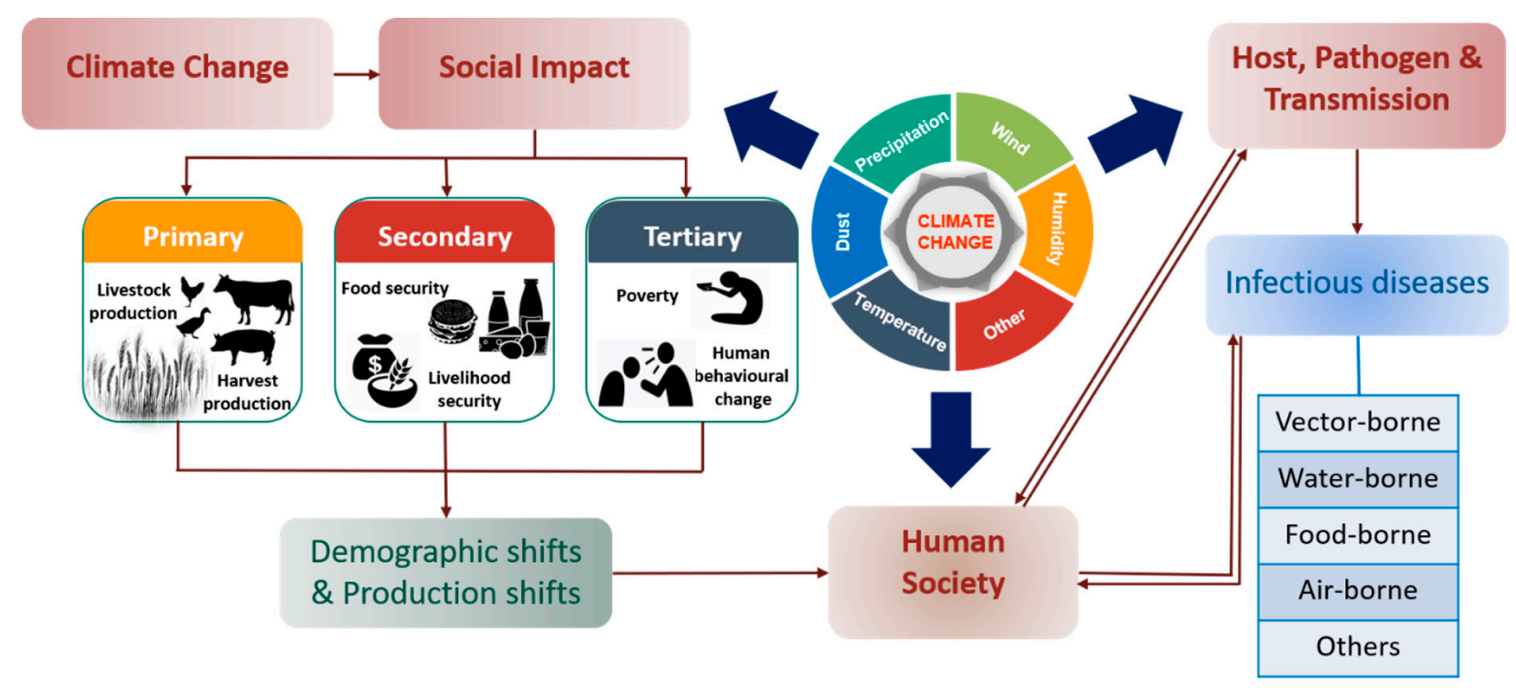

Figure 3. Social impact of climate change affecting livelihood, human society and infectious diseases adapted from [6-10,128-130].

\subsection{Climate Change and Public Health System}

Among all the mitigation measures for reducing the vulnerability of health risks associated with climate change, improved public health system and quality infrastructure are most significant [26]. Underdeveloped and developing countries are more vulnerable to climate change and related health risks. Their inefficient public health systems in terms of resources, infrastructure and capabilities are the major cause of minimal resistance towards elevated health risks. It was the below par performance of public health services and lack of anti-malaria spraying that caused more than 75,000 cases of malaria after a hurricane incidence in 1963 in Haiti [136]. Similar tragedy occurred in Guatemala, Honduras and Nicaragua where dengue and malaria morbidity rates rapidly increased after Hurricane Mitch in 1998 [137]. A similar pattern was observed in the outbreak of Vibrio cholera after the earthquake and hurricane due to poor sanitary systems [138]. A striking increase in a group of infectious diseases such as hepatitis, measles, typhoid, malaria and paratyphoid fever were found after five months of hurricane calamity in Dominican Republic in 1979. It was believed that the major causes were crowded dwellings, poor sanitation, unhygienic food and water, and low immunization rates [56]. The outburst of H5N1 in 2006 was also believed to be due to lack of efforts by the Egyptian government towards control and prevention. This ultimately resulted in the shortage and improper supply of commercial H5 
poultry vaccines [139]. It is apparent that with quality public health services, advanced infrastructure, public programs and functions, and proper government monitoring, health risks associated with climate change can be potentially minimized.

\subsection{Climate Change and Adaptation Measures}

Proper adaptation measures against climate change can play a significant role in addressing challenges regarding infectious diseases. Reforestation, proper sanitation, and improved drainage systems are some of the measures recommended by the United Nations Environment Programme (UNEP) in 2013 in African countries in order to mitigate climate change [140]. Hess et al. highlighted two distinct view points on climate change consequences and responses to public health. The first view argues that climate change will enhance the adverse impacts on human health; however, providing increased investment to health-related infrastructure with considerable funding and support can restrict the health impacts. Contrastingly, the second view focusses on the fact that climate change can also affect human health by destabilizing public health systems, which may indirectly pose a threat to infrastructure; thus, a broad understanding is required on adaptation [141,142].

Accurate weather forecast can be considered one of the important adaptation measures through which the public can get ample time to prepare for weather-related health risks. For example, during an El Nino weather event in 1997/98, the Pacific ENSO Application Center (PEAC) warned governments regarding severe droughts and tropical cyclones. Numerous public awareness programs and campaigns were then launched, which resulted in a remarkable reduction in hospital admission cases with diarrhea, malaria, dengue and other vector-borne diseases [110]. Another example is the case in Botswana, where a successful forecast was made regarding the outbreak of malaria [143]. However, these forecasts are not always reliable, considering the confined knowledge of complex weather patterns, particularly extreme weather events [29].

\subsection{Climate Change and Adaptation Policy}

Implementation of climate change-related policies or adaptation policies with long-term vision can greatly help in reducing the risks of adverse health impacts [144,145]. Adaptation policy refers to policy design and implementation in order to minimize the risks introduced by climate change [146]. These policies must be designed considering future scenarios and ample flexibility to tackle future complications [145-148]. A quality adaptation policy must consider governance capabilities over responsiveness, reflexivity, revitalization, and resilience [149]. Most South Asian countries like Nepal, Bangladesh and even India greatly lack effective climate change policies [150].

Recently, researchers also revealed the relative significance of discrete emotions such as hope, interest and worry in designing climate change policies around the world [151]. As a part of future research, it may be interesting to investigate the extent of positive emotions and linked potential solutions to climate change. There might be a considerable possibility that positive emotions matter more than negative emotions cohorted with climate change impacts [151]. A high compassion state will elicit stronger belief among the public that climate-related humanitarian crisis is solely because of anthropogenic activities. This can mediate further support for quality climate change policy designing, especially among political conservatives [152].

The main obstacles that influence any adaptation measure revolves around the following six factors that link climatic variables to adverse health impacts: complexity in disease patterns and mortality, food, water and sanitation, extreme events, population, human adaptation measures and capabilities. The following are considered responsible for five major challenges in developing an effective policy response framework: poverty and equity-related, informational, technological, institutional and sociopolitical [144-152]. 


\subsection{Climate Change and Social Development}

Social development in itself can play a vital role in reducing elevated health risks related to climate change. The relative number of infectious diseases after an extreme weather event such as a hurricane or a tropical cyclone are much more in underdeveloped and developing countries when compared to developed nations [153]. In 1998, the Dominican Republic faced widespread acute respiratory infection and gastrointestinal infections due to the occurrence of Hurricane Georges [154]. In addition, Hurricane Mitch of 1998 caused high dengue and malaria morbidity rates due to lack of awareness and substandard health-related infrastructure in Guatemala, Honduras and Nicaragua [137]. In contrast with the earlier-mentioned health issues, a study conducted by Toole revealed that no positive cases with infectious diseases were found in the post-hurricane analysis report [155]. In rural India, around 360 million people do not have access to toilets and more than 600 million people defecate in the open [156,157]. India faced an estimated loss of around $\$ 54$ billion in 2006 due to health-related issues, out of which $70 \%$ were due to issues related to inadequate sanitation systems [158]. Lack of environmental awareness, poor education regarding public health, limited medical resources, financial crises and limitless corruption in underdeveloped and developing countries bind these societies to more health-related challenges.

\section{Discussion and Conclusions}

Climate change refers to the long-term and sudden fluctuations in weather conditions. These fluctuations can promote a suitable environment for the sustenance of pathogens and vectors, which ultimately result in outbreaks of various human diseases. Climate variables such as temperature, wind, precipitation, and humidity constrain the spatiotemporal distribution of pathogens and their vectors. Any change in these climate variables can result in exponential reproduction, survival and distribution of disease-causing pathogens and intermediate hosts. Hazardous meteorological and weather events in combination have severe impacts on numerous infectious diseases and may increase the complications manifold. Thereby, it becomes imperative to develop relationships between climate change, pathogens, vectors, and related diseases.

Humans are highly vulnerable to the threats of infectious diseases imposed by climate change. Therefore, humans themselves must play a prime role in the adaptation and implementation of proactive measures for the alleviation of adverse health influences of climate change. Researchers have confirmed that the effects of changing climate variables throw more challenges and problems in some communities and societies than others. Hence, instead of global projections, regional projections for climate variables are required for minimizing health implications. In addition, due to lack of resources and abilities, specific areas and certain populations are more prone to the associated risks and challenges. There is the utmost requirement of teamwork between healthcare providers, scientific researchers and governments in developing as well as developed countries to work towards the upliftment of underprivileged societies. This can significantly reduce the vulnerability of incapable societies towards elevated health risks linked with climate change. The exposure of infectious diseases to humans can be reduced significantly through effective adaptation measures and positive human responses against climate change; for example, frequent allocation of required resources related to finance and health care and promotion of awareness programs. Integration of health surveillance with terrestrial and marine monitoring systems may prove more beneficial through advanced satellite imaging and forecasts. Effective early alert systems combined with integrated mapping of consequences, expenses and conditions can facilitate efficient public health mediation with proper designing of policies. Human capability to counter the negative health effects posed by climate change depends heavily on the generation of relevant, reliable and accurate information. Strengthening scientific, technological, and informational capacity within local and regional levels can be crucial for the establishment of a rejuvenated public health movement. This capacity enhancement can significantly reduce vulnerability and induce resilience in infrastructures at local, regional and national levels. 
Researchers pursuing scientific investigations on climate change and related health risks can be primarily divided into three groups: The first group examines complex issues employing experimental and modeling studies to predict the possible relationship between health risks and climate variables-trying to figure out all possible alternatives to minimize the potential risk of human diseases associated with any change in climatic conditions. The second group of researchers seeks to calculate which climatic variables and to what extent may prove beneficial for a group of disease pathogens, vectors and mode of transmission. The last group deals with extreme weather events and related economic losses. This group also thoroughly analyses the elevated psychological health risks post each extreme weather event. The limited communication and lack of collaboration among these sections have resulted in a void between understanding of climatic variables and the forecast of changing the landscape for human diseases. This can also be seen through various contradictions between authors in their outcomes. As discussed earlier, there is the strong need for precise and accurate prediction for any change in climate variables and to timely identify all possible health risks. Therefore, to improve weather predictions and human adaptation capability, all aforementioned research groups should work under the same umbrella. If not, external support should be provided to enhance effective collaboration and effortless communication so that any negative health effect can be minimized. Furthermore, as multidisciplinary and a variety of approaches are involved in the mitigation processes, a much broader view is required to provide in-depth knowledge and understanding of the correlations between climatic variables and human health. For any detailed research, high-quality and precise modeling is a prerequisite. Time series models such as Error Correction Models (ECM), Auto Regressive Moving Average with exogenous variables (ARMAX), and non-parametric forecasting models; panel data and spatial models such as spatial lag and spatial error models, fixed and random effect models, and dynamic panel data models; and non-statistical approaches such as Computable General Equilibrium (CGE), Comparative Risk Assessments models (CRA), and Integrated Assessment Models (IAMs) are some of the models that need to be properly used wherever required. This will not only help in converging the gap in the present state of understanding but can also provide more realistic data suitable for accurate predictions for any consequences.

The following three levels of practices need to be adapted for successful vindication of adverse impacts of climate change on disease occurrence: (a) improved and stringent policies must be implemented to reduce carbon emission by utilizing renewable resources and to promote carbon utilization by employing carbon dioxide sequestration technologies such as bio-sequestration or chemical sequestrations technologies, (b) detailed research is needed to identify all possible acquaintances between climatic variables and the emergence and re-emergence of infectious diseases, (c) appropriate infrastructure with improved public health systems should be available to successfully encounter adverse outcomes at the regional, state and national levels. We hope that the present review work can provide a cause for more multi-disciplinary projects and collaborations, which can converge the gap in understanding the complicated relationship between climate change and induced health risk.

Climate change is reported to be responsible for millions of deaths and billions of major or minor disabilities since its start in the 1970s $[159,160]$. The Intergovernmental Panel on Climate Change (IPCC) also predicted that the existing human health risks will be exacerbated in the coming decades [161]. Climate change-associated dilemmas such as droughts, floods, heatwaves, fires, water and vector-borne diseases, water scarcity, and shortage of food pose serious threats and will continue to target more vulnerable groups like the poor, children, pregnant women and the elderly [162,163]. In this century, adverse health impacts due to climate change will continue to rise; a few diseases may disappear, but a majority will emerge and transmit more rapidly. The most effective approach to reducing climate change induced health risk is through adaptation of proper measures, which can be identified through scientific investigations and social advances. Scientific understandings are required to move beyond the empirical observations to connect the links between climate shift and emerging diseases, and to reach more reliable conclusions. These approaches need accurate information about the climate change related outcome of health implications. Moreover, advanced modeling and simulation techniques 
are required for proper long-term analysis of climate change-based spatiotemporal processes. Being dexterous in figuring this arduous process can be the foundation of accurate prediction of health consequences of climate change and the espousal of efficient adaptation measures. Finally, for such advancements, new protocols will be required for safe and effective sharing of information, resources, and awareness campaigns.

Author Contributions: Conceptualization, M.D.K. and H.H.T.V.; data curation, M.D.K., H.H.T.V. and L.Q.T.; formal analysis, M.D.K. and H.H.T.V.; methodology, M.D.K.; project administration, J.W.A.; supervision, J J.W.A.; writing-original draft M.D.K.; writing-review \& editing, M.D.K. and J.W.A.

Funding: This work was supported by the National Research Council of Science \& Technology (NST) grant by the Korea government (MSIT) (No. CAP-18-09-KIGAM)

Acknowledgments: The authors appreciate the support received from National Strategic Project-Carbon Mineralization Flagship Center of the National Research Foundation of Korea (NRF).

Conflicts of Interest: The authors declare no conflict of interest.

\section{References}

1. McMichael, A.J. Globalization, climate change, and human health. N. Engl. J. Med. 2013, 368, 1335-1343. [CrossRef] [PubMed]

2. Solomon, S.; Qin, D.; Manning, M.; Chen, Z.; Marquis, M.; Averyt, K.B.; Tignor, M. Summary for policymakers. Contribution of Working Group 1 to the Fourth Assessment Report of the Intergovernmental Panel on Climate Change. Intergovernmental Panel on Climate Change (IPCC). In Climate Change 2007: The Physical Science Basis; Miller, H.L., Ed.; Cambridge University Press: Cambridge, UK; New York, NY, USA, 2007; Available online: https://www.ipcc.ch/publications_and_data/publications_ipcc_fourth_assessment_report_ wg1_report_the_physical_science_basis.htm (accessed on 2 August 2018).

3. Christiansen, T.; Voigt, T. Impact of Europe's Changing Climate-2008 Indicator-Based Assessment. In Joint EEA-JRC-WHO Report; European Environment Agency: Copenhagen, Denmark, 2008; Available online: https://ec.europa.eu/jrc/sites/jrcsh/files/jrc_reference_report_2008_09_climate_change.pdf (accessed on 2 August 2018).

4. Watson, R.T. A Contribution of Working Groups I, II, and III to the Third Assessment Report of the Intergovernmental Panel on Climate Change. Intergovernmental Panel on Climate Change (IPCC). In Climate Change 2001: Synthesis Report; Team, C.W., Ed.; Cambridge University Press: Cambridge, UK; New York, NY, USA, 2001; Available online: https://www.ipcc.ch/pdf/climate-changes-2001/synthesis-syr/english/front.pdf (accessed on 2 August 2018).

5. Hansen, J.; Sato, M.; Ruedy, R.; Lo, K.; Lea, D.W.; Medina-Elizade, M. Global temperature change. Proc. Natl. Acad. Sci. USA 2006, 103, 14288-14293. [CrossRef] [PubMed]

6. Epstein, P.R. Is global warming harmful to health? Sci. Am. 2000, 283, 50-57. [CrossRef] [PubMed]

7. Epstein, P.R. Climate change and emerging infectious diseases. Microbes Infect. 2001, 3, 747-754. [CrossRef]

8. Rigby, C.W.; Rosen, A.; Berry, H.L.; Hart, C.R. If the land's sick, we're sick: The impact of prolonged drought on the social and emotional well-being of Aboriginal communities in rural New South Wales. Aust. J. Rural Health 2011, 19, 249-254. [CrossRef] [PubMed]

9. Sartore, G.; Hoolahan, B.; Tonna, A.; Kelly, B.; Stain, H. Wisdom from the drought: Recommendations from a consultative conference. Aust. J. Rural Health 2005, 13, 315-320. [CrossRef]

10. Wu, X.X.; Tian, H.Y.; Zhou, S.; Chen, L.F.; Xu, B. Impact of global change on transmission of human infectious diseases. Sci. China Earth Sci. 2014, 57, 189-203. [CrossRef]

11. Harvell, C.D.; Mitchell, C.E.; Ward, J.R.; Altizer, S.; Dobson, A.P.; Ostfeld, R.S.; Samuel, M.D. Climate warming and disease risks for terrestrial and marine biota. Science 2002, 296, 2158-2162. [CrossRef]

12. Zhou, Y.B.; Zhuang, J.L.; Yang, M.X.; Zhang, Z.J.; Wei, J.G.; Peng, W.X.; Zhao, G.M.; Zhang, S.M.; Jiang, Q.W. Effects of low temperature on the schistosome-transmitting snail Oncomelania hupensis and the implications of global climate change. Molluscan Res. 2010, 30, 102-108. 
13. Henderson, A.; Leake, C.J.; Burke, D.S. Japanese encephalitis in Nepal. Lancet 1983, 2, 1359-1360. [CrossRef]

14. Bista, M.B.; Shrestha, J.M. Epidemiological situation of Japanese encephalitis in Nepal. J. Nepal. Med. Assoc. 2005, 44, 51-56. [CrossRef]

15. Impoinvil, D.E.; Solomon, T.; Schluter, W.W.; Rayamajhi, A.; Bichha, R.P.; Shakya, G.; Caminade, C.; Baylis, M. The spatial heterogeneity between Japanese encephalitis incidence distribution and environmental variables in Nepal. PLoS ONE 2011, 6, e22192. [CrossRef] [PubMed]

16. Joshi, D.D.; Sharma, M.; Bhandari, S. Visceral leishmaniasis in Nepal during 1980-2006. J. Commun. Dis. 2006, 38, 139-148. [PubMed]

17. Pun, S.B.; Sato, T.; Pandey, K.; Pandey, B.D. Changing trends in visceral leishmaniasis: 10 years' experience at a referral hospital in Nepal. Trans. R. Soc. Trop. Med. Hyg. 2011, 105, 550-554. [CrossRef]

18. Department of Health Services. Annual Report 2069/70 (2012/2013) Kathmandu: Department of Health Services, Ministry of Health and Population, Government of Nepal; Department of Health Services: Kathmandu, Nepal, 2014. Available online: http://dohs.gov.np/wp-content/uploads/2014/04/Annual_Report_2069_70.pdf (accessed on 2 August 2018).

19. Adhikari, R.K.; Bhusal, K.P. Surveillance of lymphatic filariasis in selected districts of Nepal. J. Inst. Med. 2008, 30, 35-40.

20. Slaper, H.; Velders, G.J.M.; Matthijsen, J. Ozone depletion and skin cancer incidence: A source risk approach. J. Hazard Mater. 1998, 61, 77-84. [CrossRef]

21. Verbrugge, L.M.; Rainey, J.J.; Reimink, R.L.; Blankespoor, H.D. Swimmer's itch: Incidence and risk factors. Am. J. Public Health. 2004, 94, 738-741. [CrossRef]

22. Cheng, A.; Currie, B. Melioidosis: Epidemiology, pathophysiology, and management. Clin. Microbiol. Rev. 2005, 18, 383-416. [CrossRef]

23. Kuhn, K.; Campbell-Lendrum, D.; Haines, A.; Cox, J. Using Climate to Predict Infectious Diseases Epidemics; World Health Organization: Geneva, Switzerland, 2005; Available online: http://www.who.int/globalchange/ publications/infectdiseases/en/ (accessed on 2 August 2018).

24. Antia, R.; Regoes, R.; Koella, J.; Bergstrom, C. The role of evolution in the emergence of infectious diseases. Nature 2013, 426, 658-661. [CrossRef]

25. Ogden, N.H.; Lindsay, L.R. Effects of climate and climate change on vectors and vector-borne diseases: Ticks are different. Trends Parasitol. 2016, 32, 646-656. [CrossRef]

26. Wu, X.; Li, Y.; Zhou, S.; Chen, L.; Xu, B. Impact of climate change on human infectious diseases: Empirical evidence and human adaptation. Environ. Int. 2016, 86, 14-23. [CrossRef] [PubMed]

27. Barros, V.; Stocker, T.F.; Qin, D.; Dokken, D.J.; Ebi, K.L.; Mastrandrea, M.D.; Mach, K.J.; Plattner, G.-K.; Allen, S.K.; Tignor, M.; et al. Managing the Risks of Extreme Events and Disasters to Advance Climate Change Adaptation: Special Report of Working Groups I and II of the Intergovernmental Panel on Climate Change; Midgley, P.M., Ed.; Intergovernmental Panel on Climate Change; Cambridge University Press: Cambridge, UK; New York, NY, USA, 2012; Available online: https://www.ipcc.ch/pdf/special-reports/srex/SREX_Full_ Report.pdf (accessed on 8 August 2018).

28. Zhu, Y.; Toth, Z. Extreme weather events and their probabilistic prediction by the NCEP ensemble forecast system. In Proceedings of the 81st American Meteorological Society Annual Meeting, Albuquerque, NM, USA, 14-19 January 2001; Available online: https://ams.confex.com/ams/annual2001/webprogram/Paper17656.html (accessed on 4 August 2018).

29. Lubchenco, J.; Karl, T.R. Predicting and managing extreme weather events. Phys. Today 2012, 65, 31-37. [CrossRef]

30. Nicholls, N.E. El Nino-Southern Oscillation and vector-borne disease. Lancet 1993, 342, 1284-1285. [CrossRef]

31. Hay, S.I.; Cox, J.; Rogers, D.J.; Randolph, S.E.; Stern, D.I.; Shanks, G.D.; Myers, M.F.; Snow, R.W. Climate change and the resurgence of malaria in the East African highlands. Nature 2002, 415, 905-909. [CrossRef] [PubMed]

32. Shanks, G.D.; Hay, S.I.; Stern, D.I.; Biomndo, K.; Snow, R.W. Meteorologic influences on Plasmodium falciparum malaria in the highland tea estates of Kericho, western Kenya. Emerg. Infect. Dis. 2002, 8, 1404-1408. [CrossRef] [PubMed] 
33. Linthicum, K.J.; Anyamba, A.; Tucker, C.J.; Kelley, P.W.; Myers, M.F.; Peters, C.J. Climate and satellite indicators to forecast Rift Valley fever epidemics in Kenya. Science 1999, 285, 397-400. [CrossRef] [PubMed]

34. Davies, F.G.; Linthicum, K.J.; James, A.D. Rainfall and epizootic Rift Valley fever. Bull. World Health Organ. 1985, 63, 941-943. [PubMed]

35. McMichael, A.J.; Lindgren, E. Climate change: Present and future risks to health, and necessary responses. J. Intern. Med. 2011, 270, 401-413. [CrossRef] [PubMed]

36. Louis, M.E.; Hess, J.J. Climate change. Impacts on and implications for global health. Am. J. Prev. Med. 2008, 35, 527-538. [CrossRef]

37. Haines, A.; Kovats, R.S.; Campbell-Lendrum, D.; Corvalan, C. Climate change and human health: Impacts, vulnerability, and mitigation. Lancet 2006, 367, 2101-2109. [CrossRef]

38. Haines, A.; Kovats, R.S.; Campbell-Lendrum, D.; Corvalan, C. Climate change and human health: Impacts, vulnerability and public health. Public Health 2006, 120, 585-596. [CrossRef] [PubMed]

39. Barnett, A.G.; Dobson, A.J.; McElduff, P.; Salomaa, V.; Kuulasmaa, K.; Sans, S.; WHO MONICA Project. Cold periods and coronary events: An analysis of populations worldwide. Epidemiol. Community Health 2005, 59, 551-557. [CrossRef] [PubMed]

40. Meehl, G.A.; Tebaldi, C. More intense, more frequent, and longer lasting heat waves in the 21st century. Science 2004, 305, 994-997. [CrossRef] [PubMed]

41. Medina-Ramon, M.; Zanobetti, A.; Cavanagh, D.P.; Schwartz, J. Extreme temperatures and mortality: Assessing effect modification by personal characteristics and specific cause of death in a multicity case-only analysis. Environ. Health Perspect. 2006, 114, 1331-1336. [CrossRef] [PubMed]

42. Abrignani, M.G.; Corrao, S.; Biondo, G.B.; Renda, N.; Braschi, A.; Novo, G.; Di Girolamo, A.; Braschi, G.B.; Novo, S. Influence of climatic variables on acute myocardial infarction hospital admissions. Int. J. Cardiol. 2009, 137, 123-129. [CrossRef] [PubMed]

43. Mireku, N.; Wang, Y.; Ager, J.; Reddy, R.C.; Baptist, A.P. Changes in weather and the effects on pediatric asthma exacerbations. Ann. Allergy Asthma Immunol. 2009, 103, 220-224. [CrossRef]

44. Lin, S.; Luo, M.; Walker, R.J.; Liu, X.; Hwang, S.A.; Chinery, R. Extreme high temperatures and hospital admissions for respiratory and cardiovascular diseases. Epidemiology 2009, 20, 738-746. [CrossRef] [PubMed]

45. Duffy, P.B.; Tebaldi, C. Increasing prevalence of extreme summer temperatures in the US. Clim. Chang. 2012, 111, 487-495. [CrossRef]

46. Ganguly, A.R.; Steinhaeuser, K.; Erickson, D.J.; Branstetter, M.; Parish, E.S.; Singh, N.; Drake, J.B.; Buja, L. Higher trends but larger uncertainty and geographic variability in 21st century temperature and heat waves. Proc. Natl. Acad. Sci. USA 2009, 106, 15555-15559. [CrossRef]

47. Centers for Disease Control and Prevention. Heat-related deaths-Four states, July-August 2001, and United States, 1979-1999. Morb. Mortal. Wkly. Rep. 2002, 51, 567-570.

48. Bhaskaran, K.; Hajat, S.; Haines, A.; Herrett, E.; Wilkinson, P.; Smeeth, L. Effects of ambient temperature on the incidence of myocardial infarction. Heart 2009, 95, 1760-1769. [CrossRef] [PubMed]

49. Lim, Y.-H.; Hong, Y.-C.; Kim, H. Effects of diurnal temperature range on cardiovascular and respiratory hospital admissions in Korea. Sci. Total Environ. 2012, 417-418, 55-60. [CrossRef] [PubMed]

50. Chen, H.X. The influence of flood and drought on the epidemic of hemorrhagic fever with renal syndrome and prevention measures. Chin. J. Public Health 1999, 15, 665.

51. Pan, H.M.; Cheng, D.M.; Shi, Y.N. The influence of flood disasters to the leptospirosis epidemic. Chin. J. Nat. Med. 2003, 5, 73-75.

52. Sanders, E.J.; Rigau-Perez, J.G.; Smits, H.L.; Deseda, C.C.; Vorndam, V.A.; Aye, T.; Spiegel, R.A.; Weyant, R.S.; Bragg, S.L. Increase of leptospirosis in dengue-negative patients after a hurricane in Puerto Rico in 1996. Am. J. Trop. Med. Hyg. 1999, 61, 399-404. [CrossRef]

53. Shultz, J.M.; Russel, J.; Espinel, Z. Epidemiology of tropical cyclones: The dynamics of disaster, disease, and development. Epidemiol. Rev. 2005, 27, 21-35. [CrossRef] [PubMed]

54. Delfino, R.J.; Brummel, S.; Wu, J.; Stern, H.; Ostro, B.; Lipsett, M.; Winer, A.; Street, D.H.; Zhang, L.; Tjoa, T.; et al. The relationship of respiratory and cardiovascular hospital admissions to the southern California wildfires of 2003. Occup. Environ. Med. 2009, 66, 189-197. [CrossRef] [PubMed] 
55. Jaffe, D.A.; Wigder, N.L. Ozone production from wildfires: A critical review. Atmos. Environ. 2012, 51, 1-10. [CrossRef]

56. Ebi, K.L.; Exuzides, K.A.; Lau, E.; Kelsh, M.; Barnston, A. Association of normal weather periods and El Nino events with hospitalization for viral pneumonia in females: California, 1983-1998. Am. J. Public Health 2001, 91, 1200-1208. [CrossRef]

57. Chretien, J.P.; Anyamba, A.; Bedno, S.A.; Breiman, R.F.; Sang, R.; Sergon, K.; Powers, A.M.; Onyango, C.O.; Small, J.; Tucker, C.J. Drought-associated Chikungunya emergence along coastal East Africa. Am. J. Trop. Med. Hyg. 2007, 76, 405-407. [CrossRef]

58. Dwight, R.H.; Baker, D.B.; Semenza, J.C.; Olson, B.H. Health effects associated with recreational water use: Urban versus rural California. Am. J. Public Health 2004, 94, 565-567. [CrossRef] [PubMed]

59. Dai, A. Drought under global warming: A review. Wiley Interdiscip. Rev. Clim. Chang. 2010, 2, 45-65. [CrossRef]

60. Reacher, M.; McKenzie, K.; Lane, C.; Nichols, T.; Kedge, I.; Iversen, A.; Hepple, P.; Walter, T.; Laxton, C.; Simpson, J. Health impacts of flooding in Lewes: A comparison of reported gastrointestinal and other illness and mental health in flooded and non-flooded households. Commun. Dis. Public Health 2004, 7, 39-46. [PubMed]

61. Hajat, S.; O'Connor, M.; Kosatsky, T. Health effects of hot weather: from awareness of risk factors to effective health protection. The Lancet 2010, 375, 856-863. [CrossRef]

62. Van Doorn, H.R. Emerging infectious diseases. Medicine 2017, 45, 798-801. [CrossRef]

63. Taylor, L.H.; Latham, S.M.; Woolhouse, M.E.J. Risk factors for human diseases emergence. Philos. Trans. R. Soc. Lond. B Biol. Sci. 2001, 356, 983-989. [CrossRef] [PubMed]

64. Mellor, P.S.; Leake, C.J. Climate and geographic influences on arboviral infection and vectors. Rev. Sci. Tech. 2000, 19, 41-54. [CrossRef]

65. Tian, H.Y.; Bi, P.; Cazelles, B.; Zhou, S.; Huang, S.Q.; Yang, J.; Pei, Y.; Wu, X.X.; Fu, S.H.; Tong, S.L.; et al. How environmental conditions impact mosquito ecology and Japanese encephalitis: An eco-epidemiological approach. Environ. Int. 2015, 79, 17-24. [CrossRef]

66. Bunyavanich, S.; Landrigan, C.P.; McMichael, A.J.; Epstein, P.R. The impact of climate change on child health. Ambul. Pediatr. 2003, 3, 44-52. [CrossRef]

67. Perencevich, E.N.; McGregor, J.C.; Shardell, M.; Furuno, J.P. Summer peaks in the incidences of gram-negative bacterial infection among hospitalized patients. Infect. Control Hosp. Epidemiol. 2008, 29, 1124-1131. [CrossRef]

68. Anderson, D.J.; Herve, R.; Chen, L.F.; Spelman, D.W.; Hung, Y.; Huang, A.T.; Sexton, D.J.; Raoult, D. Seasonal variation in Klebsiella pneumoniae bloodstream infection on 4 continents. J. Infect. Dis. 2008, 197, 752-756. [CrossRef] [PubMed]

69. Patz, J.A.; Epstein, P.R.; Burke, T.A.; Balbus, J.M. Global climate change and emerging infectious diseases. J. Am. Med. Assoc. 1996, 275, 217-223. [CrossRef]

70. Schuffenecker, I.; Iteman, I.; Michault, A.; Murri, S.; Frangeul, L.; Vaney, M.C.; Lavenir, R.; Pardigon, N.; Reynes, J.M.; Pettinelli, F. Genome microevolution of chikungunya viruses causing the Indian Ocean outbreak. PLoS Med. 2006, 3, e263. [CrossRef] [PubMed]

71. Frank, C.; Littman, M.; Alpers, K.; Hallauer, J. Vibrio vulnificus wound infections after contact with the Baltic Sea, Germany. Eur. Surg. 2006, 11, E060817. [CrossRef] [PubMed]

72. Haley, B.J.; Cole, D.J.; Lipp, E.K. Distribution, diversity, and seasonality of waterborne Salmonellae in a rural watershed. Appl. Environ. Microbiol. 2009, 75, 1248-1255. [CrossRef] [PubMed]

73. Kay, D.; McDonald, A.T. Predicting coliform concentrations in upland impoundments: Design and calibration of a multivariate model. Appl. Environ. Microbiol. 1983, 46, 611-618. [PubMed]

74. El-Fadel, M.; Ghanimesh, S.; Maroun, R.; Alameddine, I. Climate change and temperature rise: Implications on food- and water-borne diseases. Sci. Total Environ. 2012, 437, 15-21. [CrossRef] [PubMed]

75. Wilby, R.L.; Hedger, M.; Orr, H. Climate change impacts and adaptation: A science agenda for the Environmental Agency of England and Wales. Weather 2005, 60, 206-211. [CrossRef]

76. Jofre, J.; Blanch, A.R.; Lucena, F.; Sabater, S. Water-borne infectious disease outbreaks associated with water scarcity and rainfall events. In Water Scarcity in the Mediterranean: Perspectives Under Global Change; Barcelo, D., Ed.; The Handbook of Environmental Chemistry; Springer: Berlin/Heidelberg, Germany, 2010; Volume 8, pp. 147-159, ISBN 978-3-642-03971-3. 
77. Xu, B.; Jin, Z.Y.; Jiang, Z.B.; Guo, J.P.; Timberlake, M.; Ma, X.L.; Weng, Q. Climatological and geographical impacts on global pandemic of influenza A (H1N1). In Global Urban Monitoring and Assessment through Earth Observation, 1st ed.; Taylor \& Francis/CRC Press: Boca Raton, FL, USA, 2014; ISBN 9781466564503.

78. Lowen, A.C.; Mubareka, S.; Steel, J.; Palese, P. Influenza virus transmission is dependent on relative humidity and temperature. PLoS Pathog. 2007, 3, 1470-1476. [CrossRef] [PubMed]

79. Thu, H.M.; Aye, K.M.; Thein, S. The effect of temperature and humidity on dengue virus propagation in Aedes aegypti mosquitos. Southeast Asian J. Trop. Med. Public Health 1998, 29, 280-284. [PubMed]

80. Chen, P.S.; Tsai, F.T.; Lin, C.K.; Yang, C.Y.; Chan, C.C.; Young, C.Y.; Lee, C.H. Ambient influenza and avian influenza virus during dust storm days and background days. Environ. Health Perspect. 2010, 118, 1211-1216. [CrossRef] [PubMed]

81. Reiter, P. Climate change and mosquito-borne disease. Environ. Health Perspect. 2001, 109, $141-161$. [CrossRef]

82. Mills, J.N.; Gage, K.L.; Khan, A.S. Potential influence of climate change on vector-borne and zoonotic diseases: A review and proposed research plan. Environ. Health Perspect. 2010, 118, 1507-1514. [CrossRef] [PubMed]

83. Rogers, D.J.; Randolph, S.E. Climate change and vector-borne diseases. Adv. Parasitol. 2006, 62, 345-381. [CrossRef] [PubMed]

84. Liu-Helmersson, J.; Quam, M.; Wilder-Smith, A.; Stenlund, H.; Ebi, K.; Massad, E.; Rocklov, J. Climate change and Aedes Vectors: 21st century projections for dengue transmission in Europe. EBioMedicine 2016, 7, 267-277. [CrossRef] [PubMed]

85. Shrestha, U.B.; Gautam, S.; Bawa, K.S. Widespread climate change in the Himalayas and associated changes in local ecosystems. PLoS ONE 2012, 7, e36741. [CrossRef]

86. Sakya, G.M. Present Status of Malaria in Nepal. J. Nepal Med. Assoc. 1981, 19, 21-28. [CrossRef]

87. Dhimal, M.; Ahrens, B.; Kuch, U. Malaria control in Nepal 1963-2012: Challenges on the path towards elimination. Malar. J. 2014, 13, 241. [CrossRef]

88. Department of Health Services. Annual Report 2068/69 (2011/2012) Kathmandu: Department of Health Services, Ministry of Health and Population, Government of Nepal, Kathmandu; Department of Health Services: Kathmandu, Nepal, 2013. Available online: http://www.nnfsp.gov.np/PortalContent.aspx?Doctype=Resources\&ID=228 (accessed on 5 September 2018).

89. Malla, S.; Thakur, G.D.; Shrestha, S.K.; Banjeree, M.K.; Thapa, L.B.; Gongal, G.; Ghimire, P.; Upadhyay, B.P.; Gautam, P.; Khanal, S.; et al. Identification of all dengue serotypes in Nepal. Emerg. Infect. Dis. 2008, 14, 1669-1670. [CrossRef]

90. Pandey, B.D.; Nabeshima, T.; Pandey, K.; Rajendra, S.P.; Shah, Y.; Adhikari, B.R.; Gupta, G.; Gautam, I.; Tun, M.M.; Uchida, R.; et al. First isolation of dengue virus from the 2010 epidemic in Nepal. Trop. Med. Health 2013, 41, 103-111. [CrossRef]

91. Dhimal, M.; Gautam, I.; Kress, A.; Muller, R.; Kuch, U. Spatio-temporal distribution of dengue and lymphatic filariasis vectors along an altitudinal transect in Central Nepal. PLoS Negl. Trop. Dis. 2014, 8, e3035. [CrossRef] [PubMed]

92. Lauterbach, R.; Wells, K.; O'Hara, R.B.; Kalko, E.K.; Renner, S.C. Variable strength of forest stand attributes and weather conditions on the questing activity of Ixodes ricinus ticks over years in managed forests. PLoS ONE 2013, 8, e55365. [CrossRef] [PubMed]

93. Jore, S.; Vanwambeke, S.O.; Viljugrein, H.; Isaksen, K.; Kristoffersen, A.B.; Worldehiwet, Z.; Johansen, B.; Brun, E.; Brun-Hansen, H.; Westermann, S.; et al. Climate and environmental change drives Ixodes ricinus geographical expansion at the northern range margin. Parasites Vectors 2014, 7, 11. [CrossRef] [PubMed]

94. Jaenson, T.G.T.; Jaenson, D.G.E.; Eisen, L.; Petersson, E.; Lindgren, E. Changes in the geographical distribution and abundance of the tick Ixodes ricinus during the past 30 years in Sweden. Parasites Vectors 2012, 5, 8. [CrossRef] [PubMed]

95. Korotkov, Y.; Kozlova, T.; Kozlovskaya, L. Observations on changes in abundance of questing Ixodes ricinus, castor bean tick, over a 35-year period in the eastern part of its range (Russia, Tula region). Med. Vet. Entomol. 2015, 29, 129-136. [CrossRef] [PubMed]

96. Lafferty, K.D. The ecology of climate change and infectious diseases. Ecology 2009, 90, 888-900. [CrossRef] [PubMed] 
97. Tabachnick, W.J. Challenges in predicting climate and environmental affects on vector-borne disease episystems in a changing world. J. Exp. Biol. 2010, 213, 946-954. [CrossRef] [PubMed]

98. Parham, P.E.; Waldock, J.; Christophides, G.K.; Hemming, D.; Agusto, F.; Evans, K.J.; Fefferman, N.; Gaff, H.; Gumel, A.; LaDeau, S.; et al. Climate, environmental and socio-economic change: Weighing up the balance in vector-borne disease transmission. Philos. Trans. R. Soc. Lond. B Biol. Sci. 2015, 370. [CrossRef]

99. Bayoh, M.N.; Lindsay, S.W. Temperature-related duration of aquatic stages of the Afrotropical malaria vector mosquito Anopheles gambiae in the laboratory. Med. Vet. Entomol. 2004, 18, 174-179. [CrossRef]

100. Christiansen-Jucht, C.; Parham, P.E.; Saddler, A.; Koella, J.C.; Basáñez, M.G. Temperature during larval development and adult maintenance influences the survival of Anopheles gambiae s.s. Parasites Vectors 2014, 7 , 489. [CrossRef]

101. Paaijmans, K.P.; Imbahale, S.S.; Thomas, M.B.; Takken, W. Relevant microclimate for determining the development rate of malaria mosquitoes and possible implications of climate change. Malar. J. 2010, 9, 196. [CrossRef] [PubMed]

102. Eisen, L.; Monaghan, A.J.; Lozano-Fuentes, S.; Steinhoff, D.F.; Hayden, M.H.; Bieringer, P.E. The impact of temperature on the bionomics of Aedes (Stegomyia) aegypti, with special reference to the cool geographic range margins. J. Med. Entomol. 2014, 51, 496-516. [CrossRef] [PubMed]

103. Briscoe, M.S. Aedes aegypti the yellow fever mosquito, its life history, bionomics and structure. J. Natl. Med. Assoc. 1962, 54, 132.

104. Beck-Johnson, L.M.; Nelson, W.A.; Paaijmans, K.P.; Read, A.F.; Thomas, M.B.; Bjørnstad, O.N. The Effect of Temperature on Anopheles Mosquito Population Dynamics and the Potential for Malaria Transmission. PLoS ONE 2013, 8, e79276. [CrossRef] [PubMed]

105. Hoshen, M.B.; Morse, A.P. A weather-driven model of malaria transmission. Malar. J. 2004, 3, 32. [CrossRef]

106. Zell, R. Global climate change and the emergence/re-emergence of infectious diseases. Int. J. Med. Microbiol. Suppl. 2004, 293, 16-26. [CrossRef]

107. Epstein, P.R. West Nile virus and the climate. J. Urban Health 2001, 78, 367-371. [CrossRef]

108. Gage, K.L.; Burkot, T.R.; Eisen, R.J.; Hayes, E.B. Climate and vectorborne diseases. Am. J. Prev. Med. 2008, 35, 436-450. [CrossRef]

109. Kovats, R.S.; Bouma, M.J.; Hajat, S.; Worrall, E.; Haines, A.E. Niño and health. Lancet 2003, 362, 1481-1489. [CrossRef]

110. Hamnett, M.P.; Anderson, C.L.; Guard, C.P. The Pacific ENSO Applications Center and the 1997-98 ENSO Warm Event in the US-affiliated Micronesian Islands: Minimizing Impacts Through Rainfall Forecasts and Hazard Mitigation; Pacific ENSO Applications Center: Honolulu, HI, USA, 1999; Available online: http://www.hazards-climate-environment.org/yahoo_site_admin/assets/docs/HCEP_Technical_ Reports_Plans_Updated.142163831.pdf (accessed on 4 July 2018).

111. Reid, C. Implications of Climate Change on Malaria in Karnataka, India. Thesis (Honors), Brown University, Providence, RI, USA, 2000.

112. Snow, K.R.; Medlock, J.M. The potential impact of climate change on the distribution and prevalence of mosquitoes in Britain. Eur. Mosq. Bull. 2006, 21, 1-10.

113. Service, M.W. Ecological and biological studies on Aedes cantans in southern England. J. Applied Ecol. 1977, 14, 159-196. [CrossRef]

114. Bates, P.A. Leishmania sand fly interaction: Progress and challenges. Curr. Opin. Microbiol. 2008, 11, $340-344$. [CrossRef] [PubMed]

115. European Food Safety Authority, European Centre for Disease Prevention and Control. The community summary report on trends and sources of zoonoses and zoonotic agents in the European Union in 2007. EFSA J. 2009, 7, 223r. [CrossRef]

116. Kovats, R.S.; Edvards, S.J.; Charron, D.; Cowden, J.; D’Souza, R.M.; Ebi, K.L.; Gauci, C.; Gerner-Smidt, P.; Hajat, S.; Hales, S.; et al. Climate variability and campylobacter infection: An international study. Int. J. Biometeorol. 2005, 49, 207-214. [CrossRef] [PubMed]

117. Bannister, L.; Mitchell, G. The ins, outs and round-abouts of malaria. Trends Parasitol. 2003, 19, $209-213$. [CrossRef]

118. Carpenter, S.; Wilson, A.; Barber, J.; Veronesi, E.; Mellor, P.; Venter, G.; Gubbins, S. Temperature dependence of the extrinsic incubation period of Orbiviruses in Culicoides biting midges. PLoS ONE 2011, 6, e27987. [CrossRef] 
119. Danforth, M.E.; Reisen, W.K.; Barker, C.M. Extrinsic incubation rate is not accelerated in recent California strains of West Nile Virus in Culex tarsalis (Diptera: Culicidae). J. Med. Entomol. 2015, 52, 1083-1089. [CrossRef] [PubMed]

120. Medlock, J.M.; Avenell, D.; Barrass, I.; Leach, S. Analysis of the potential for survival and seasonal activity of Aedes albopictus (Diptera: Culicidae) in the United Kingdom. J. Vector Ecol. 2006, 31, 292-304. [CrossRef]

121. Jones, K. Campylobacters in water, sewage and the environment. J. Appl. Microbiol. 2001, 90, 68S-79S. [CrossRef]

122. Ebi, K.L.; Nealon, J. Dengue in a changing climate. Environ. Res. 2016, 151, 115-123. [CrossRef]

123. Chien, L.C.; Yu, H.L. Impact of meteorological factors on the spatiotemporal patterns of dengue fever incidences. Environ. Int. 2014, 73, 46-56. [CrossRef] [PubMed]

124. Barrett, A.D.T.; Higgs, S. Yellow fever: A disease that has yet to be conquered. Annu. Rev. Entomol. 2007, 52, 209-220. [CrossRef] [PubMed]

125. Adlouni, S.E.; Beaulieu, C.; Ouarda, T.B.M.J.; Gosselin, P.L.; Saint-Hilaire, A. Effects of climate on West Nile Virus transmission risk used for public health decision-making in Quebec. Int. J. Health Geogr. 2007, 6, 40. [CrossRef] [PubMed]

126. Tian, H.Y.; Zhou, S.; Dong, L.; Van Boeckel, T.P.; Cui, Y.J.; Wu, Y.R.; Cazelles, B.; Huang, S.Q.; Yang, R.F.; Grenfell, B.T.; et al. Avian influenza H5N1 viral and bird migration networks in Asia. Proc. Natl. Acad. Sci. USA 2015, 112, 172-177. [CrossRef] [PubMed]

127. Engelthaler, D.M.; Mosley, D.G.; Cheek, J.E.; Levy, C.E.; Komatsu, K.K.; Ettestad, P.; Davis, T.; Tanda, D.T.; Miller, L.; Frampton, J.W. Climatic and environmental patterns associated with hantavirus pulmonary syndrome, Four Corners region, United States. Emerg. Infect. Dis. 1999, 5, 87-94. [CrossRef] [PubMed]

128. Semenza, J.C.; Menne, B. Climate change and infectious diseases in Europe. Lancet Infect. Dis. 2009, 9, 365-375. [CrossRef]

129. Li, R.; Jiang, Z.B.; Xu, B. Global spatiotemporal and genetic footprint of the H5N1 avian influenza virus. Int. J. Health Geogr. 2014, 13, 14. [CrossRef]

130. Wang, Y.; Jiang, Z.B.; Jin, Z.Y.; Tan, H.Y.; Xu, B. Risk factors for infectious diseases in backyard poultry farms in the Poyang lake area, China. PLoS ONE 2013, 8, e67366. [CrossRef]

131. Bai, L.; Woodward, A.; Liu, Q. Temperature and mortality on the roof of the world: A time-series analysis in three Tibetan counties. Sci. Total Environ. 2014, 485, 41-48. [CrossRef]

132. Jiang, Q.; Zhou, J.; Jiang, Z.B.; Xu, B. Identifying risk factors of avian infectious disease at household level in Poyang Lake region, China. Prev. Vet. Med. 2014, 116, 151-160. [CrossRef]

133. Akhtar, R.; Dutt, A.; Wadhwa, V. Health Planning and the Resurgence of Malaria in Urban India. In Urban Health in the Third World; Nangia, S.B., Akhtar, R., Eds.; A.P.H. Publishing Corporation: New Delhi, India, 2002; ISBN 81-7648-293-5. Available online: https://books.google.co.kr/books?id=k8-4cckH9WcC\&printsec= frontcover\&source $=$ gbs_ge_summary_r\&cad $=0 \# \mathrm{v}=$ onepage $\& \mathrm{q} \& \mathrm{f}=$ false (accessed on 7 September 2018).

134. Shah, I.; Deshpande, G.C.; Tardeja, P.N. Outbreak of dengue in Mumbai and predictive markers for dengue shock syndrome. J. Trop. Pediatr. 2004, 50, 301-305. [CrossRef] [PubMed]

135. Lloyd, S.J.; Kovats, R.S.; Armstrong, B.G. Global diarrhoea morbidity, weather and climate. Clim. Res. 2007, 34, 119-127. [CrossRef]

136. Bissell, R.A. Delayed-impact infectious disease after a natural disaster. J. Emerg. Med. 1983, 1, 59-66. [CrossRef]

137. Pan American Health Organization. Impact of Hurricane Mitch on Central America. Epidemiol. Bull. 1998, 19,1-14. Available online: http://www1.paho.org/english/sha/epibul_95-98/be984mitch.htm (accessed on 7 September 2018).

138. Kouadio, I.K.; Aljunid, S.; Kamigaki, T.; Hammad, K.; Oshitani, H. Infectious Diseases Following Natural Disasters: Prevention and Control Measures. Expert Rev. Anti-Infect. Ther. 2012, 10, 95-104. [CrossRef] [PubMed]

139. Abdelwhab, E.; Selim, A.; Arafa, A.; Galal, S.; Kilany, W.; Hassan, M.; Aly, M.; Hafez, M. Circulation of avian influenza H5N1 in live bird markets in Egypt. Avian Dis. 2010, 54, 911-914. [CrossRef] [PubMed]

140. Rowling, M. Africa Faces Sharp Rise in Climate Adaptation Costs, UNEP; Thomson Reuters Foundation: London, UK, 2013; Available online: http://news.trust.org//item/20131119134543-8whnr/?source=hptop (accessed on 18 September 2018). 
141. Hess, J.J.; Mcdowell, J.Z.; Luber, G. Integrating climate change adaptation into public health practice: Using adaptive management to increase adaptive capacity and build resilience. Environ. Health Perspect. 2012, 120, 171-179. [CrossRef] [PubMed]

142. Austin, S.E.; Biesbroek, R.; Berrang-Ford, L.; Ford, J.D.; Parker, S.; Fleury, M.D. Public health adaptation to climate change in OECD countries. Int. J. Environ. Res. Public Health 2016, 13, 889. [CrossRef]

143. Thomson, M.C.; Doblas-Reyes, F.J.; Mason, S.J.; Hagedorn, R.; Connor, S.J.; Phindela, T.; Morse, A.P.; Palmer, T.N. Malaria early warnings based on seasonal climate forecasts from multi-model ensembles. Nature 2006, 439, 576-579. [CrossRef]

144. Rasul, G. Food, water: And energy security in South Asia: A nexus perspective from the Hindu Kush Himalayan region. Environ. Sci. Policy 2014, 39, 35-48. [CrossRef]

145. Di Gregorio, M.; Nurrochmat, D.R.; Paavola, J.; Sari, I.M.; Fatorelli, L.; Pramova, E.; Locatelli, B.; Brockhaus, M.; Kusumadewi, S.D. Climate policy integration in the land use sector: Mitigation: Adaptation and sustainable development linkages. Environ. Sci. Policy 2017, 67, 35-43. [CrossRef]

146. Dessai, S.; Hulme, M. Does climate adaptation policy need probabilities? Clim. Policy 2004, 4, 107-128. [CrossRef]

147. Pahl-Wostl, C. A conceptual framework for analyzing adaptive capacity and multi-level learning processes in resource governance regimes. Glob. Environ. Chang. 2009, 19, 354-365. [CrossRef]

148. Hasnoot, M.; Kwakkel, J.H.; Walker, W.E.; Ter Maat, J. Dynamic adaptative policy pathways: A method for crafting robust decisions for a deeply uncertain world. Glob. Environ. Chang. 2013, 23, 485-498. [CrossRef]

149. Termeer, C.J.; Dewulf, A.; Breeman, G.; Stiller, S.J. Governance capabilities for dealing wisely with wicked problems. Adm. Soc. 2015, 47, 680-710. [CrossRef]

150. Kreft, S.; Eckstein, D.; Junghans, L.; Kerestan, C.; Hagen, U. Global Climate Risk Index 2015; German Watch: Glashutte, Germany, 2014; pp. 3-59, ISBN 978-3-943704-23-5. Available online: https://germanwatch.org/ sites/germanwatch.org/files/publication/10333.pdf (accessed on 18 September 2018).

151. Smith, N.; Leiserowitz, A. The role of emotion in global warming policy support and opposition. Risk Anal. 2014, 34, 937-948. [CrossRef] [PubMed]

152. Lu, H.; Schuldt, J.P. Compassion for climate change victims and support for mitigation policy. J. Environ. Psychol. 2016, 45, 192-200. [CrossRef]

153. Guill, C.K.; Shandera, W.X. The effects of Hurricane Mitch on a community in northern Honduras. Prehosp. Disaster Med. 2001, 16, 166-171. [CrossRef] [PubMed]

154. Centers for Disease Control and Prevention (CDC). Needs assessment following Hurricane Georges-Dominican Republic, 1998. Morb. Mortal. Wkly Rep. 1999, 48, 93-95. [CrossRef]

155. Toole, M.J. Communicable Diseases and Disease Control. In The Public Health Consequences of Disasters; Noji, E., Ed.; Oxford University Press: New York, NY, USA, 1997; ISBN 978-0195095708.

156. O'reilly, K.; Dhanju, R.; Goel, A. Exploring "the remote" and "the rural": Open defecation and latrine use in Uttarakhand, India. World Dev. 2017, 93, 193-205. [CrossRef]

157. The World Health Organization (WHO)/The United Nations Children's Fund (UNICEF). Progress in Drinking Water and Sanitation; WHO: Geneva, Switzerland, 2014; ISBN 9789241507240. Available online: https: //www.unicef.org/publications/files/JMP_report_2014_webEng.pdf (accessed on 18 September 2018).

158. Kumar, S.G.; Kar, S.S.; Jain, A. Health and environmental sanitation in India: Issues for prioritizing control strategies. Indian J. Occup. Environ. Med. 2011, 15, 93-96. [CrossRef] [PubMed]

159. Haines, A.; McMichael, A.J.; Smith, K.R.; Roberts, I.; Woodcock, J.; Markandya, A.; Armstrong, B.G.; Campbell-Lendrum, D.; Dangour, A.D.; Davies, M.; et al. Public health benefits of strategies to reduce greenhouse-gas emissions: Overview and implications for policy makers. Lancet 2009, 374, 2104-2114. [CrossRef]

160. Patz, J.A.; Campbell-Lendrum, D.; Holloway, T.; Foley, J.A. Impact of regional climate change on human health. Nature 2005, 438, 310-317. [CrossRef] [PubMed]

161. Collins, M.R.; Knutti, J.; Arblaster, J.L.; Dufresne, T.; Fichefet, P.; Friedlingstein, X.; Gao, W.J.; Gutowski, T.; Johns, G.; Krinner, M.; et al. Long-term climate change: Projections, commitments and irreversibility. In Climate Change 2013. The Physical Science Basis. Contribution of Working Group I to the Fifth Assessment Report of the Intergovernmental Panel on Climate Change; Stocker, T.F., Qin, D., Plattner, G.-K., Tignor, M., Allen, S.K., Boschung, J., Nauels, A., Xia, Y., Bex, V., Midgley, P.M., Eds.; Cambridge University Press: Cambridge, UK; New York, NY, USA, 2013; p. 1535, ISBN 9781107057999. 
162. Smith, K.R.; Woodward, A.; Campbell-Lendrum, D.; Chadee, D.; Honda, Y.; Qiyong Liu, Q.; Olwoch, J.; Revich, B.; Sauerborn, R. Human Health: Impacts, Adaptation, and Co-Benefits. In Climate Change 2014: Impacts, Adaptation, and Vulnerability. Contribution of Working Group II to the Fifth Assessment Report of the Intergovernmental Panel on Climate Change; Cambridge University Press: Cambridge, UK, 2014; Available online: https://www.ipcc.ch/pdf/assessment-report/ar5/syr/SYR_AR5_FINAL_full_wcover.pdf (accessed on 19 September 2018).

163. Luber, G.; Knowlton, K.; Balbus, J.; Frumkin, H.; Hayden, M.; Hess, J.; McGreehin, M.; Sheats, N.; Backer, L.; Beard, C.B.; et al. Human Health. Climate Change Impacts in the United States: The Third National Climate Assessment; Melillo, J.M., Terese, T.C., Yohe, G.W., Eds.; U.S. Global Change Research Program: Washington, DC, USA, 2014; pp. 220-256. Available online: https://digital.library.yorku.ca/yul-1120588/chapter-9human-health-climate-change-impacts-united-states-third-national-climate (accessed on 19 September 2018). [CrossRef]

(C) 2019 by the authors. Licensee MDPI, Basel, Switzerland. This article is an open access article distributed under the terms and conditions of the Creative Commons Attribution (CC BY) license (http://creativecommons.org/licenses/by/4.0/). 